\title{
Učinci politike oporezivanja duhanskih prerađevina u Europskoj uniji u razdoblju 2005.-2014.
}

\author{
Antić, Dinka
}

Source / Izvornik: Odabrani prijevodi, 2015, 6, 1 - 22

Journal article, Published version

Rad u časopisu, Objavljena verzija rada (izdavačev PDF)

https://doi.org/10.3326/op.32

Permanent link / Trajna poveznica: https:/urn.nsk.hr/urn:nbn:hr:242:450668

Rights / Prava: Attribution-NonCommercial-NoDerivatives 4.0 International/ImenovanjeNekomercijalno-Bez prerada 4.0 međunarodna

Download date / Datum preuzimanja: 2023-04-26

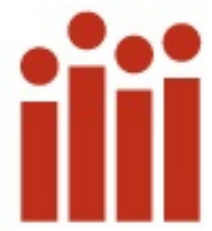

Institute of Public Finance Repository

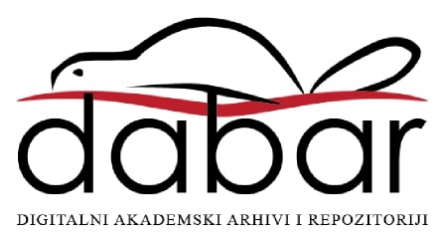


Institut za

javne financije

Smičiklasova 2I | Zagreb

www.ijf.hr | ured@ijf.hr

T: oI/4886-444 | F: OI/48I9-365

\section{ODABRANI}

\section{PRIJEVODI}

ISSN I847-7445

BR. 32/I5

citirati: Antić, D. 20I5. Implications of the taxation of tobacco in the European Union in the period 200520I4. Financial Theory and Practice, 39 (3), str. 279-304. Dostupno na: $<$ http://www.fintp.hr/upload/files/f tp/2015/3/antic.pdf $>$.

Svi Odabrani prijevodi dostupni su na: http://www.ijf.hr/hr/publikacije/ca sopisi/I2/odabrani-prijevodi/III/

\section{UČINCI POLITIKE OPOREZIVANJA DUHANSKIH PRERAĐEVINA U EUROPSKOJ UNIJI U RAZDOBLJU 2005.-20I4.}

DR.sc. DiNKA ANTIĆ

PREGLEDNI ČLANAK**

JEL: $\mathrm{H} 2$

DOI: $10.3326 /$ op.32

\section{SAŽETAK}

U radu se analiziraju učinci politike oporezivanja trošarinama u članicama i na razini EU-a u razdoblju 2005-20I4. u području približavanja politika oporezivanja duhanskih prerađevina, ostvarivanja poreznih prihoda i tržišta duhana. Na temelju statističkih metoda varijabilnosti utvrđuje se politika približavanja sustava oporezivanja trošarinama među članicama EU-a u području oporezivanja cigareta iz čega proizlazi da su trošarinske politike novih članica homogenije nego u EU-I5. Prema trendovima potrošnje duhanskih prerađevina može se zaključiti kako je politika utemeljena na povećanju trošarina na cigarete uz održavanje niske trošarine na sitno rezani duhan dovela u većini zemalja članica do iskrivljenosti na tržištu duhana i do gubitak trošarinskih prihoda. Istraživanje prikazano u ovom radu potvrdilo je ključnu hipotezu kako se jedinstvena i učinkovita trošarinska politika na razini EU-a ne može postići bez pomnog podešavanja strukture, iznosa $i$ dinamike povećanja poreznog opterećenja cigareta i svih proizvoda koji se pojavljuju kao supstituti.

Ključne riječi: oporezivanje duhanskih prerađevina, približavanje politika oporezivanja trošarinama
Autorica zahvaljuje trojici anonimnih recenzenata na korisnim primjedbama i prijedlozima.

${ }^{* *}$ Primljeno: 3. veljače 2015.

Prihvaćeno: 24. travnja 2015.

Dinka ANTIĆ

Odjel za makroekonomsku analizu, Upravni odbor Uprave za indirektno oporezivanje Bosne i Hercegovine, Bana Lazarevića bb, 78000 Banjaluka, Bosna i Hercegovina

e-mail: dinka.antic@uino.gov.ba 


\section{UVOD}

Kao što Adam Smith navodi u svojoj knjizi Bogatstvo naroda (1776), duhan i duhanske prerađevine pogodna su dobra za oporezivanje. Budući da ne predstavljaju osnovne prehrambene namirnice i nisu dobra opće potrošnje, a uzimajući u obzir postojanje snažne ovisnosti o potrošnji, oporezivanje tih proizvoda visokim stopama može donijeti značajne prihode. U posljednjih nekoliko godina visoke stope trošarina nisu samo značajan instrument fiskalne politike nego su također u skladu s primarnim ciljevima zdravstvene politike. U skladu s jednim od šest najvažnijih instrumenata programa MPOWER ${ }^{\mathrm{I}}$, Svjetska zdravstvena organizacija (WHO, 2008) potiče povećanje trošarina na duhanske prerađevine kako bi se obeshrabrila potrošnja, posebice ona visoko rizičnih skupina i potrošnja duhana niže kvalitete. Budući da pušenje duhana proizvodi negativne eksternalije na zdravlje pušača i pasivnih pušača, prihodi od trošarina na duhanske prerađevine također se koriste za financiranje zdravstvenog sustava (Rechel i McKee, 2014).

S obzirom da potrošnja cigareta ima dominantan udio na tržištu duhanskih prerađevina, najvažniji problem je određivanje strukture stopa trošarina na cigarete $\mathrm{u}$ smislu odnosa ad valorem i specifične trošarine. Za svaku zemlju koja nastoji s tržišta ukloniti duhan niže kvalitete i smanjiti zdravstvene rizike ovo je ključno pitanje. Struktura trošarina na cigarete također je važna za proces približavanja trošarinskih politika članica EU-a u smjeru stvaranja povezanije trošarinske politike na razini EU-a. U posljednjih sto godina trendovi na tržištu duhana ukazuju da je sustav oporezivanja ostalih duhanskih prerađevina koji se pojavljuju kao supstituti cigaretama od bitne važnosti u kreiranju učinkovite trošarinske politike. U posljednjih nekoliko godina znatno je poraslo korištenje sitno rezanog duhana za savijanje cigareta što je uzrokovalo poremećaje na tržištu duhana, porast sive ekonomije i ilegalne trgovine, a time i pad prihoda od trošarina. Očito je da zamjena cigareta sitno rezanim duhanom postaje čimbenik koji ne samo da ugrožava ostvarivanje ciljeva fiskalne i zdravstvene politike, nego i umanjuje do sada postignute rezultate $u$ borbi protiv potrošnje duhana, posebice među ranjivim skupinama i mladima.

Cilj je rada istražiti učinke dizajna trošarinske politike u EU i njezinim članicama u razdoblju 2005.2014. s naglaskom na razvoj procesa približavanja trošarinskih politika duhanskih prerađevina koje zagovara EU i na problem povećanja zamjene cigareta sitno rezanim duhanom. Cilj je istraživanja potvrditi hipotezu da trošarinska politika EU-a ne može biti učinkovita u postizanju ekonomskih, fiskalnih i zdravstvenih ciljeva bez harmonizacije sustava oporezivanja između cigareta kao glavnih prerađevina i ostalih duhanskih prerađevina koje se pojavljuju kao supstituti. Drugi dio rada analizira trendove u oporezivanju cigareta, a treći dio stupanj približavanja trošarinskih politika na razini EU-a. Četvrti dio sadrži analizu trendova na tržištu duhana i ostvarivanju trošarinskih prihoda te posljedica trenutno različitih trošarinskih politika. Smjernice za preispitivanje trošarinske politike EU-a u području sitno rezanog duhana razmatraju se u petom poglavlju. Istraživanje se temelji na bazi podataka Europske komisije CIRCABC ${ }^{2}$ za razdoblje 2005.-20I4. koja sadrži sve elemente politike zemalja članica EU-27 bitne pri oporezivanju cigareta i sitno rezanog duhana, kao i podatke o potrošnji duhanskih prerađevina i prihoda od trošarina u navedenom razdoblju³.

\footnotetext{
${ }^{1}$ MPOWER znači: Nadgledanje uporabe duhana i politika prevencije; Zaštita ljudi od duhanskog dima; Pružanje pomoći oko prestanka pušenja; Upozorenja o štetnosti duhana; Poticanje zabrana oglašavanja duhana, promocija i sponzorstva; Povećanje poreza na duhanske prerađevine.

${ }_{2}^{2}$ Dostupno na: 〈https:/ / circabc.europa.eu/faces/jsp/extension/wai/navigation/container.jsp>.

${ }^{3}$ Potrebno je napomenuti da su podaci o trošarinskim prihodima raspoloživi do 20I3., uključivo 2013.
} 


\section{Pregled literature}

\section{I. O OPOREZIVANJU DUHANSKIH PRERAĐEVINA}

Financijska teorija zastupa načelo oporezivanja pojedinačnih dobara specifičnim porezom po jedinici mjere. Međutim, kod oporezivanja duhanskih prerađevina postoji odstupanje od ovog načela pa većina zemalja duhanske prerađevine tradicionalno oporezuje ad valorem (po vrijednosti) trošarinom. Zbog množenja s cijenom prije oporezivanja (npr. proizvođačkom cijenom) djeluju na povećanje prodajne cijene cigareta. Crawford, Keen i Smith (IFS, 20Io) ukazuju kako visoke stope ad valorem trošarine ne potiču proizvođače na ulaganje u inovacije i uporabu kvalitetnijeg duhana. Rezultat je zadržavanje postojećeg raspona cijena. Politika oporezivanja trošarinama primjenom ad valorem poreza dovodi do diferencijacije cijena pa tako povećanje trošarine nema značajniji učinak na smanjenje potrošnje jer potrošači prelaze na jeftinije cigarete. Logična posljedica politike visokih stopa ad valorem trošarine je niža razina prihoda od trošarina. S druge strane, visoke specifične trošarine prisilit će proizvođače da poboljšaju svoje poslovanje, kako bi smanjenjem cijena prije oporezivanja barem djelomično umanjili učinak povećanje trošarina. U takvim okolnostima, proizvođači su zainteresirani za ulaganje $\mathrm{u}$ inovacije, opremu i visoko kvalitetni duhan, kako bi smanjili fiksne troškove po jedinici proizvoda i povećali učinkovitost svojeg poslovanja. S obzirom da visoka trošarina dovodi do viših maloprodajnih cijena cigareta proizvedenih od jeftinijeg duhana, potrošači se opredjeljuju za cigarete proizvedene od kvalitetnijeg duhana. Posljedica je uklanjanje jeftinog duhana s tržišta i smanjenje raspona cijena između najskupljih i najjeftinijih cigareta, što sprječava seljenje određene kategorije potrošača, kao što su oni s nižim primanjima i mladi, prema jeftinijim cigaretama. U ovom slučaju, naplata prihoda od trošarina ne ovisi o politici cijena poduzeća, nego o potrošnji cigareta. S obzirom da je iz obračuna isključen učinak promjena cijena, izvjesniji su očekivani prihodi od trošarina. Isto tako, primjenom specifične trošarine postupak oporezivanja (kontrola obračuna i naplate) je jednostavniji jer nije potrebno pratiti kretanje maloprodajnih cijena. Crawford, Keen i Smith (IFS, 20Io) smatraju da izbor vrste trošarine na duhanske prerađevine ovisi o preferencijama potrošača i strukturi tržišta. Tako će ad valorem trošarina biti izabrana u uvjetima monopolski strukturiranoga tržišta i slabe diferenciranosti proizvodnje. Međutim, Chaloupka, Yurekli i Fong (2012) tvrde da ako postoji izbor između ad valorem i specifične trošarine i odluke koju vrstu trošarine odabrati, moguće je koristiti, ako je to u interesu države, i mješoviti sustav trošarina. Ako je cilj prikupljanje prihoda ili smanjenje zdravstvenih rizika, država će se tada opredijeliti za specifičnu trošarinu. S druge strane, ako želi zaštititi domaću duhansku industriju i tržište jeftinijih cigareta, država će se opredijeliti za ad valorem trošarinu. Iznoseći popis razloga "za i protiv" Yurekli (200I) zastupa koncept "najbolje od oba", odnosno hibridnu stopu trošarine koja će objedinjavati prednosti obiju vrsta trošarina.

\subsection{O UTJEGAJU ELASTIČNOSTI POTRAŽNJE DUHANSKIH PRERAĐEVINA NA OBLIKOVANJE POLITIKE}

Države se prvenstveno odlučuju za povećanje poreza kako bi ostvarile veći priljev poreznih prihoda. Mogući visoki prihodi od trošarina rezultat su neelastičnosti potražnje za duhanskim prerađevinama koji se ostvaruju čak i u slučaju povećanja cijena uzrokovanog povećanjem trošarine. Prema analizama Svjetske banke (1999) Io postotni porast poreznog opterećenja na cigarete donosi prosječni porast prihoda za $7 \%$. Povećanje poreznog opterećenja ne dovodi do proporcionalnog povećanja prihoda zbog efekta dohotka i učinka supstitucije uzrokovanog oporezivanjem. Veće porezno opterećenje 
neminovno dovodi do smanjenja potrošnje, ali s druge strane, potrošači pokušavaju izbjeći ili smanjiti porezni teret kako bi održali raniju razinu potrošnje. Prekomjeran rast poreza može proizvesti i suprotne učinke na rast prihoda ukoliko porezno opterećenje prijeđe prag izdržljivosti potrošača kao što pokazuje Lafferova krivulja. Daljnji nastavak politike povećanja poreznog opterećenja može ozbiljno ugroziti porezne prihode, povećati poreznu evaziju i uzrokovati širenje nelegalnog tržišta. Porast prihoda također nije proporcionalan zbog heterogenosti potrošača. Pad potrošnje veći je kod osoba nižih primanja, što dovodi do manjeg porasta prihoda od trošarina. U posljednjih pedeset godina brojna istraživanja objavljena $u$ oko stotinjak radova i studija, od koji je većina iz zemalja $s$ visokim dohocima, ukazuju da se cjenovna elastičnost kreće u rasponu između -o,25 i -0,5. U većini zemalja koncentrirana je oko -0,4 (Chaloupka i sur., 2012). Cnossen (2006) navodi Viscusijev pregled rezultata 4I istraživanja o učincima cijena cigareta na potražnju, od kojih se 3I odnosi na SAD, a ostatak na Veliku Britaniju. Elastičnost potražnja kretala se u rasponu od -o,4 do -I,o u SAD-u, a u Velikoj Britaniji između -O,I i -o,8. Istraživanja Svjetske banke (1999) pokazala su da elastičnost potražnje za cigaretama ovisi o stupnju razvijenosti zemlje. U razvijenim zemljama s visokim dohocima prosječno Io\%-tno povećanje cijene kutije cigareta dovodi do pada potrošnje od $4 \%$, dok u zemljama u razvoju koje pripadaju skupini s niskim i srednjim dohocima pad potrošnje prosječno iznosi $8 \%$.

U nekim istraživanjima zaključeno je da elastičnost potrošnje cigareta varira ovisno o parametrima razmatranja, odnosno o dohocima ili dobnoj strukturi potrošača. Brojna istraživanja tijekom posljednjeg desetljeća pokazala su da je potražnja za cigaretama cjenovno neelastična u kraćem roku, dok je u duljem razdoblju prisutan veći stupanj fleksibilnosti (Ramboll, 2014). Nadalje, potražnja za cigaretama je elastičnija kod osoba s nižim dohocima. Analize Svjetske banke (1999) pokazale su kako porast cijena cigareta $u$ većoj mjeri, zbog niskih primanja, pogađa siromašnije nego bogatije slojeva potrošača, kao i mlađu populaciju koja ima ograničene prihode. Chaloupka i sur. (2002) navode studije u kojima je utvrđeno da elastičnost potražnje cigareta kod mladih ne ovisi samo o njihovim dohocima, nego i o cijenama ostalih dobara koje mladi konzumiraju. Na temelju analize trendova u potrošnji cigareta i drugih dobara među mladima u SAD-u u vrijeme snažnog rasta cijena automobilskog goriva, vidljiva je povezanost između pada potrošnje cigareta i povećanja cijena goriva. Objašnjenje analitičara je da se mladi ljudi, kad se nađu u situaciji u kojoj moraju birati između cigareta ili vožnje automobila, odlučuju za vožnju, a time se povećava i potrošnja goriva.

Ova istraživanja o ponašanju mladih ukazuju na značaj unakrsne elastičnosti potražnje što je važno pri koncipiranju politike trošarina na duhanske prerađevine. U uvjetima postojanja unakrsne elastičnosti dobara, kupnja nekog dobra ne ovisi samo o cijeni tog dobra, nego i o cijenama supstituta ili komplementarnih dobara. Država može svojom poreznom politikom dati snažan poticaj potrošačima da legalno izbjegnu plaćanje visokih poreza, a da $\mathrm{u}$ isto vrijeme ostvare koristi od potrošnje koju su imali i prije povećanja poreza. Time se smanjuju očekivani ciljevi porezne politike. Kao rezultat poreznih mjera, a ne poboljšanja učinkovitosti u njihovoj primjeni nastaju tržišne iskrivljenosti i alokacija kapitala u smislu prebacivanja potražnje prema supstitutima. Još je Adam Smith (1776) ukazao na štetnost nejednakog oporezivanja supstituta. Obrazlaže to činjenicom da je u njegovo vrijeme uvođenje različitih trošarina na pivo $u$ Engleskoj dovelo do štetne porezne konkurencije i složenijeg sustava prikupljanja poreznih prihoda bez značajnijih fiskalnih učinaka. Stoga se Smith zalaže za porezni sustav u kojem se supstituti oporezuju jedinstvenim porezom na potrošnju. 
Empirijska istraživanja pokazuju da je glavni pokretač porezne evazije u posljednja dva desetljeća bila politika nejednakog oporezivanja cigareta i duhana koji se koristi za ručno savijanje cigareta (tzv. RYO duhan - Roll-Your-Own tobacco). Nejednako oporezivanje duhanskih prerađevina dovelo je na tržištu cigareta do migracije potrošača. Cigarete su skuplje u usporedbi sa sitno rezanim duhanom, što znači da je i veći porez na cigarete, pa se potrošači prebacuju na tržište sitno rezanog duhana koji se oporezuje nižim stopama i time je jeftiniji. Townsend (1998) navodi primjere Norveške, gdje je povećanje poreza na cigareta dovelo do povećane potrošnje ručno savijanih cigareta. I u Egiptu je povećanje poreza na cigarete uzrokovalo porast potražnje za duhanom za lule (shisha) koji se oporezuje nižim stopama. De Beyer i Yurekli (200o) ističu da se dogodila slična situacija u Indoneziji gdje je povećan porez na bijele cigarete, ali ne i na kreteks ${ }^{4}$. Ova istraživanja pokazuju da su negativni učinci različitih stopa trošarina više izraženi u manje razvijenim zemljama $s$ neučinkovitom carinskom i poreznom administracijom, slabom poreznom disciplinom, većim razmjerima korupcije, slabim mehanizmima kontrole i neučinkovitim sustavom sankcioniranja poreznih prijevara.

Opsežno istraživanje o poreznim utajama za potrebe Europske komisije koje se temeljilo na informacijama prikupljenim od carinskih službi i medija, ili intervjuiranjem proizvođača i potrošača, pokazalo je da se u EU godišnje izgubi oko I3\% prihoda od trošarina zbog nelegalnog duhana (Rambell, 2014). Za razliku od istraživanja EU-a, nedavno istraživanje o posljedicama supstitucije cigarete sitno rezanim duhanom u BiH temeljilo se na stvarnim statističkim podacima o uvozu papira za cigarete umanjenog za količinu potrebnu domaćoj proizvodnji cigareta i podacima o količini duhana potrebnog za ručno savijanje cigareta (Antić, 2014). Istraživanje je pokazalo da se omjer potrošnje ručno savijanih cigareta i potrošnje oporezivih cigarete dramatično povećava iz godine u godinu. Od neznatnih 3,6\% u 20II. godini, u 2012. poraslo je na I6\%, a u 2013. čak na 33\%. Autorica zaključuje u slučaju kad bi svi potrošači koji savijaju cigarete prešli na oporezive cigarete moguća potrošnja cigareta i dalje će biti manja od ukupne stvarne potrošnje (oporezive i neoporezive) jer je potrebno uzeti u obzir ograničenost dohotka raspoloživog za kupnju duhana i razlike u cijeni između cigareta dobivenih savijanjem i najjeftinijeg oporezivog branda.

Na primjeru Poljske moguće je zaključiti da se tržište cigareta može stabilizirati odgovarajućom trošarinskom politikom koja će obuhvatiti sve supstitute cigareta. Rast maloprodajnih cijena cigareta potaknut rastom trošarina izaziva snažne migracije potrošača prema potrošnji ručno savijanih cigareta. Povećanjem trošarina na sitno rezani duhan Poljska je samo uspjela smanjiti porezne utaje, jer su potrošači prešli na potrošnju duhana za lulu koji se oporezuje u manjoj mjeri u odnosu na cigarete i sitno rezani duhan (WHO, 2OII). Iz primjera Poljske može se zaključiti da uvijek postoji opasnost da trošarine neće obuhvatiti, ili barem ne u dovoljnoj mjeri, sve potencijalne supstitute. U uvjetima tehnoloških inovacija koje rezultiraju brzim rastom tržišta, kao što je slučaj s e-cigaretama, potrebno je točno definirati različite "granične" duhanske proizvode kako bi se izbjeglo pogrešno razvrstavanje u neoporezive proizvode te proširiti opseg oporezivanja na sirovi duhan, listove duhana, otpad, itd. (Ramboll, 2014).

Ove studije upućuju na zaključak A. Smitha da najučinkovitiji sustav trošarinske politike nužno podrazumijeva primjenu jedinstvene stope. Međutim, Cnossen (2006) ipak smatra da se dizajn trošarinske politike treba razmotriti i s gledišta troškova proizvodnje supstituta. Iako su na tržištu cigarete najvažnija duhanska prerađevina, postoje i drugi proizvodi, kao što su cigare i cigarilosi koje

\footnotetext{
${ }^{4}$ Kreteks su cigarete koje se proizvode u Indoneziji od mješavine duhana i ostalog bilja (klinčići, kumin i sl.).
} 
troši uži krug potrošača. Konačno, postoji i sitno rezani duhan, duhan za žvakanje, burmut i duhan za lulu koji se koriste za pušenje. Različite vrste duhana za pušenje koriste se za osobnu proizvodnju savijanjem cigareta. U osnovi radi se o prerađevini duhana niže kvalitete koja se prodaje po nižim cijenama i logično je da se oporezuje nižom stopom. Cnossen (2006) smatra da bi realna trošarina za I kilogram sitno rezanog duhana trebala iznositi dvije trećine trošarine na cigarete, izražene po kilogramu duhana sadržanog $\mathrm{u}$ cigaretama. Razlike $\mathrm{u}$ oporezivanju moraju odražavati razlike $\mathrm{u}$ kvaliteti i troškovima između industrijske proizvodnje cigareta i osobnog savijanja duhana.

\subsection{O POLITICI PRIBLIŽAVANJA TROŠARINSKIH POLITIKA U EUROPSKOJ UNIJI}

U svakoj zemlji pri kreiranju nacionalne trošarinske politike na duhanske prerađevine važna je odluka o izboru ad valorem, specifične ili mješovite stope trošarine, te faktori učinaka dohotka i supstitucije, elastičnosti potrošnje i unakrsne elastičnosti. Međutim, u složenoj zajednici kao što je EU nužna je koordinacija i harmonizacija politika na razini EU-a. Nezavisne nacionalne trošarinske politike mogu među članicama proizvesti negativne učinke štetne porezne konkurencije i negativno djelovati na jedinstveno tržište. Proces pozitivnog usklađivanja trošarina na duhanske prerađevine na razini EU-a, koji je započeo otvaranjem tržišta Europske zajednice i992., ubrzo je dobio novu dimenziju postupkom približavanja trošarinskih politika članica. Postupak bi trebao doprinijeti ostvarivanju ciljeva zdravstvene politike članica i EU-a (EU, 2007), kao što već u nekim članicama EU-a, npr. u Austriji, Bugarskoj, Estoniji, Finskoj, Francuskoj, Grčkoj, Poljskoj, Rumunjskoj i Velikoj Britaniji postoji povezanost trošarinske i zdravstvene politiku usmjeravanjem djela prihoda od poreza na duhanske prerađevine za financiranje javnog zdravstva (Rechel i McKee, 20I4). Cnossen (2006) istražuje učinke velikih razlika u poreznom opterećenju i cijenama cigareta unutar Unije u uvjetima slobodne trgovine među državama. Ukazuje na krijumčarenja velikih razmjera preko vanjskih granica Unije te nezakonitu prodaju i distribuciju unutar Unije što je posljedica porezne konkurencije među državama članicama. Zaključuje kako bi se harmonizacijom trošarina na duhanske prerađevine moglo umanjiti ove probleme. Empirijske studije o učincima približavanja trošarina u razdoblju 2002.-12. pokazuju brže smanjenje razlika između poreznog opterećenja trošarinama i maloprodajnih cijena $u$ starim članicama (Cooper i Witt, 2012). U isto vrijeme, zahvaljujući bržem tempu usklađivanja i nižim prihodima, nove članice su više pogođene rastom crnog tržišta i utajom poreza. Cnossen (2006) kao pozitivan učinak trošarinske politike EU-a navodi promjenu poreznog fokusa s ad valorem na specifične trošarine. Zagovara dulje prijelazno razdoblje prilagodbe za nove članice i smatra kako bi daljnje povećanje trošarina (više od 6o eura) bilo kontraproduktivno. Crawford, Keen i Smith (IFS, 2010) imaju sličan stav. Uzimajući u obzir heterogenost Unije oni vjeruju da bi nametanje visokog stupnja uniformnosti trošarina na razini EU-a proizvelo ekonomske neučinkovitosti i eroziju prihoda. Međutim, prema Yurekli (2013), takva neučinkovitost je u određenoj mjeri i očekivana s obzirom da politika trošarina na duhanske prerađevine u EU predstavlja politički kompromis, a trošarinske politike u članicama određuje i odobrava EU. S druge strane, empirijsko istraživanje o učincima jedinstvenog tržišta na trošarinsku politiku u EU u razdoblju 1987.-2004. pokazalo je da je stvaranje jedinstvenog tržišta, a time i uvođenje minimalnih standarda oporezivanja na razini EU-a, predstavljalo značajnu prekretnicu za reforme trošarinskih politika članica (Lockwood i Migali, 2008). Sve to ukazuje da je proces približavanja trošarina na duhanske prerađevine dvosmjeran i da njegova učinkovita provedba uključuje stalne međusobne prilagodbe trošarinske politike na razini EU-a i trošarinskih politika članica. 


\section{TRENDOVI U POLITIGI OPOREZIVANJA GIGARETA}

\section{I. PRAVNI OKVIR}

Duhanske prerađevine koji su predmet harmonizacije trošarina u EU obuhvaćaju cigarete, cigare i cigarilose kao i duhan za pušenje. Duhan za pušenje uključuje sitno rezani duhan i ostali duhan za pušenje. Prema Direktivi Vijeća 92/79/ EEZ o usklađivanju poreza na cigarete, države članice obvezne su propisati proporcionalnu (ad valorem) trošarinu, koja se određuje u postotku maloprodajne cijene cigareta i specifičnu trošarinu koja se obračunava prema količini, odnosno za 1.ooo komada cigareta.

Dugi niz godina osnovno obilježje $u$ području oporezivanja duhanskih prerađevina $u$ EU je podijeljenost između članica koje imaju razvijenu domaću duhansku industriju i onih koje su uglavnom uvoznice duhanskih prerađevina. Države članice s vlastitom duhanskom proizvodnjom koje su više izložene međunarodnoj konkurenciji imaju u pravilu veće stope ad valorem trošarine na cigarete kako bi zaštitile domaće brandove. Zbog različitosti nacionalnih trošarinskih politika, koje su se povećale $\mathrm{s}$ procesom proširenja EU-a, potreba za približavanjem trošarinskih politika država članica u smjeru stvaranja jedinstvene trošarinske politike EU-a zahtijevala je uvođenje minimalne trošarine. Minimalni standardi oporezivanja duhanskih prerađevina propisani su za svaku određenu skupinu. Minimalna trošarina na cigarete primjenjuje se u EU od samog početka uspostave harmoniziranog sustava trošarina (1993.) kada je Direktivom Vijeća 92/79/EEZ određena za cjenovno najpopularniju kategoriju cigareta u iznosu 57\% maloprodajne cijene ("kriterij 57\%"). U skladu s Direktivom Vijeća 95/59/EZ o porezima koji nisu porez na promet, a koji utječu na potrošnju prerađenog duhana, specifični porez mora u cijeni najpopularnije kategorija cigareta iznositi između 5 i 55\% ukupnog poreznog opterećenja (ukupna trošarina plus PDV).

Izmjenama i dopunama Direktive od I. srpnja 2002. svaka država članica obvezna je primijeniti sveukupnu minimalnu trošarinu koja obuhvaća specifičnu i ad valorem trošarinu, bez PDV-a, na razini 57\% maloprodajne cijene (uključujući sve poreze). Osim toga, porez ne može biti manji od 6o eura za I.Ooo kg cjenovno najprodavanije kategorije cigareta. One članice koje su nametnule ukupnu minimalnu trošarinu od 95 eura za I.ooo komada cjenovno najprodavanije kategorije cigareta ne moraju ispunjavati kriteriji 57\%. Sukladno dinamici povećanja stopa, Direktivom od I. srpnja 2006. minimalna ukupna trošarina povećana je na 64 eura za 1.ooo komada cigareta. Shodno tome, prag za neprimjenjivanje kriterija 57\% povećan je na IoI euro za 1.0oo komada cigareta.

Direktivom Vijeća 20II/64/EU o strukturi i stopama trošarina na prerađeni duhan od I. siječnja 2014. sveukupna minimalna trošarina povećana je na go eura za I.ooo komada cigareta. Kriterij "cjenovno najpopularnije kategorije" zbog metodoloških nedostataka i velike razlike u njegovoj primjeni unutar EU-a zamijenjen je ponderiranom prosječnom maloprodajnom cijenom. Prema tome, u odnosu na kriterij $57 \%$ od cijene cjenovno najpopularnije kategorije primjenjuje se novi obračun od $60 \%$ ponderirane prosječne cijene cigareta ("kriterij 60\%"). Donja granica za udio specifičnog poreza u ukupnom poreznom opterećenju (ukupna trošarina plus PDV) povećana je s 5\% na 7,5\%, a gornja s 55\% na $76,5 \%$. 


\subsection{TRENDOVI U POLITIGI OPOREZIVANJA}

Pri određivanju minimalnog iznosa trošarine od 60 eura Komisija je bila svjesna da neke zemlje neće moći u propisanom roku ispuniti uvjet povećanja stope. Daljnja povećanja minimalne trošarine na 64 eura, a zatim na 90 eura predstavljalo je novim članicama veliki teret. Slično, uvođenjem još zahtjevnijeg kriterija 60\% ponderirane prosječne maloprodajne cijene cigareta pojavio se problem u zemljama u kojima su prisutne velike razlike između cijena najpopularnijih, najčešće najjeftinijih brandova i ponderiranih prosječnih maloprodajnih cijena. U razvijenim zemljama razlike između ove dvije cijene su zanemarive. Iako je nova minimalna trošarina od 90 eura za 1.ooo komada cigareta propisana u 20II. godini, $u$ šest zemalja kojima je odobreno tranzicijsko razdoblje za postupak harmonizacije, trošarine su i dalje ispod propisanog minimuma, dok u pogledu kriterija $60 \%$, osam članica ima stope ispod propisanog minimuma.

Većina zemalja ugradila je u nacionalna zakonodavstva odredbe o minimalnim kriterijima promjenom strukture stopa trošarina kroz smanjenje stope ad valorem trošarine, iako su neke zemlje povećale ad valorem trošarinu (grafikon I). U razdoblju od deset godina promatrajući u cjelini EU-27, prosječne ad valorem trošarine smanjene su za 8,2 postotna poena.

Za razliku od smanjenja ad valorem trošarine, sve zemlje povećale su specifičnu trošarinu (grafikon 2). Na razini EU-a prosječna specifična trošarina povećana je $140 \%$.

\section{GRAFIKON I.}

Promjene visine ad valorem trošarine u EU (2005.-20I4.)

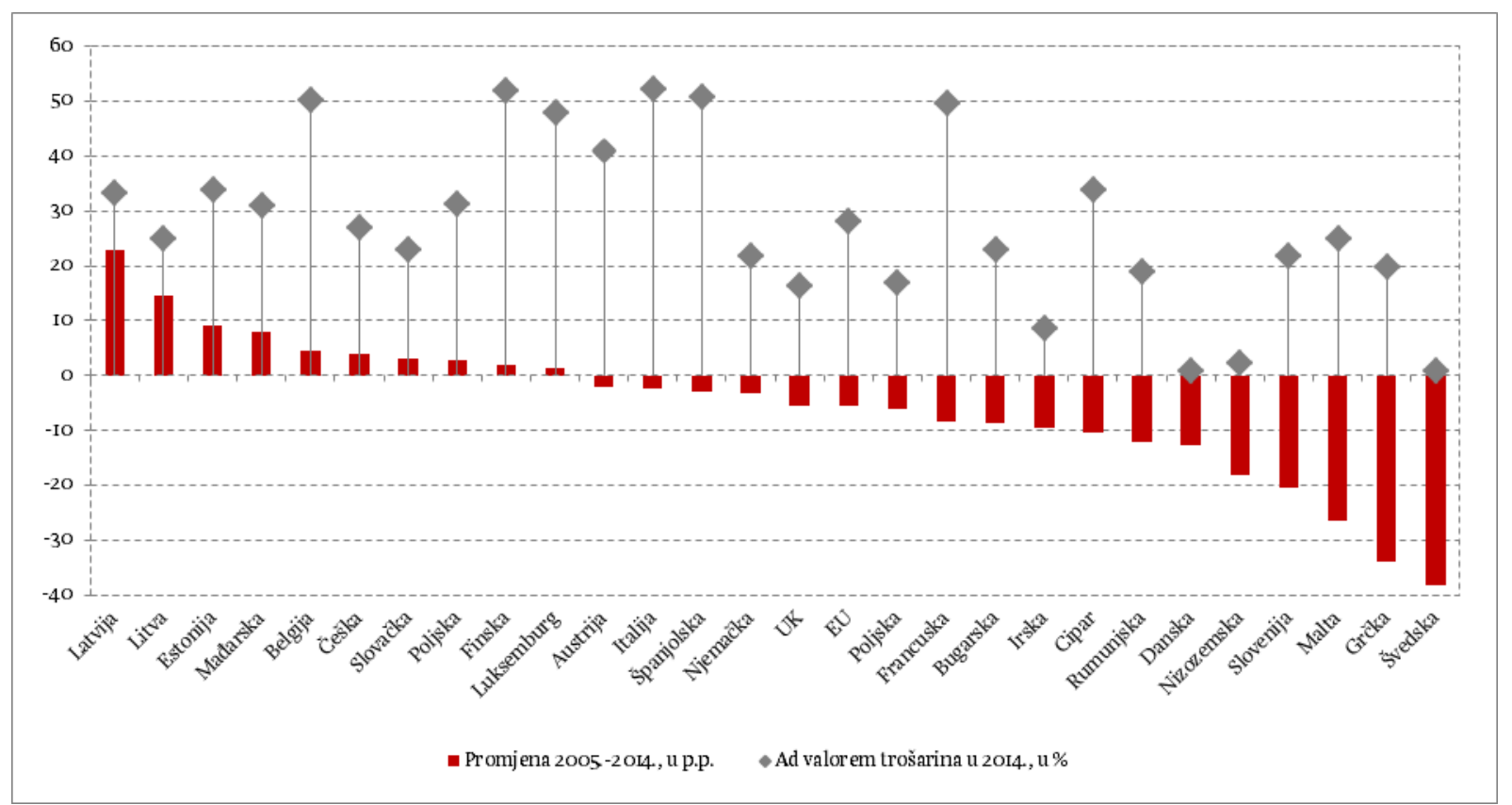

Izvor: European Commission - CIRCABC baza podataka(I990-20I4); izračun autorice. 
GRAFIKON 2.

Promjene u visini stopa specifične trošarine u EU (2005.-20I4.)

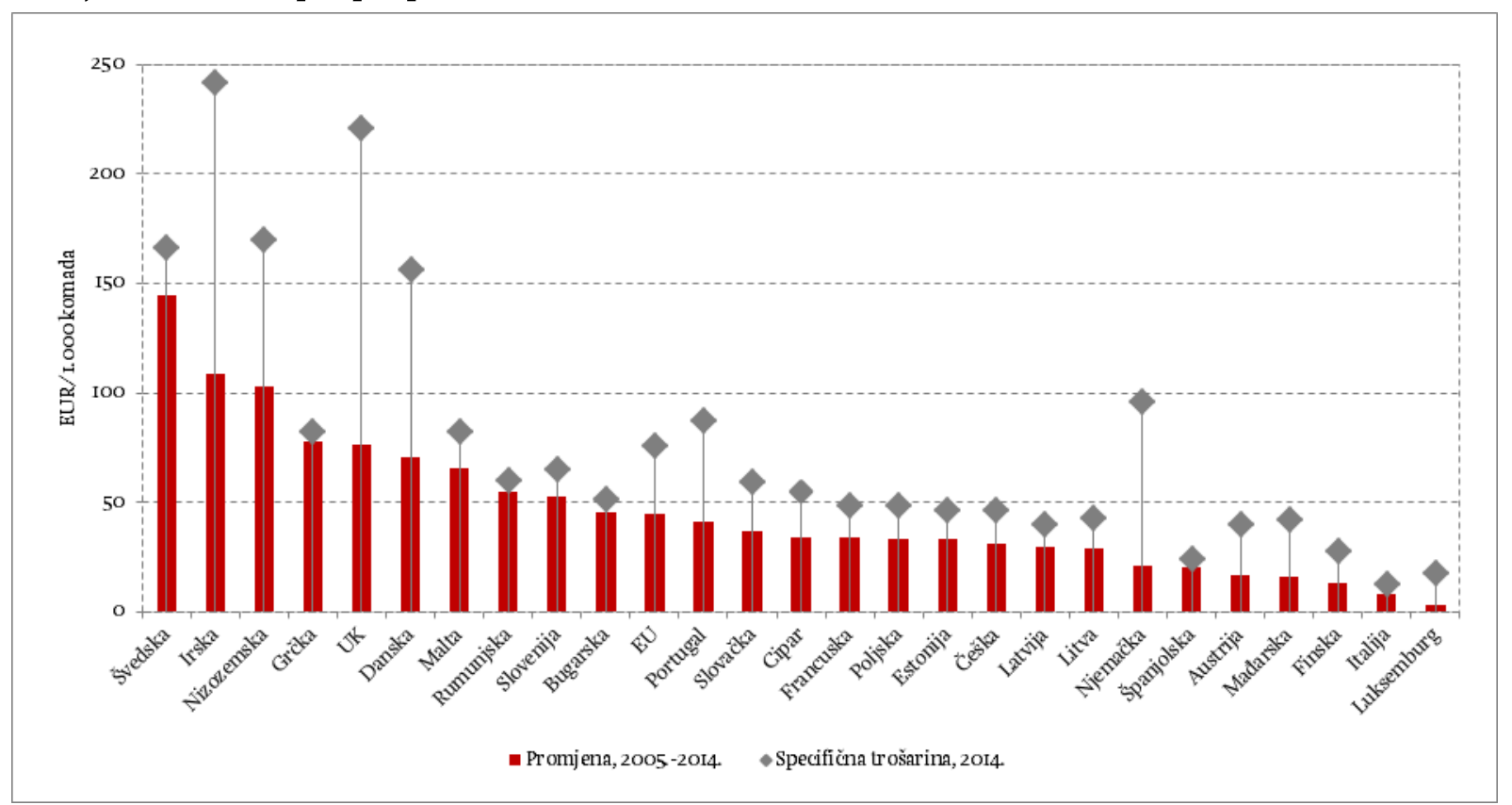

Izvor: European Commission - CIRCABC baza podataka (I990-20I4); izračun autorice.

Sve navedene promjene utjecale su na veličinu i strukturu poreznog opterećenja cigareta. U razdoblju 2005--2014. prisutno je povećanje poreznog opterećenja u svim članicama. Prosječno porezno opterećenje u cijeni cigareta u EU povećano je za $66 \%$. Kod usporedbe potrebno je uzeti u obzir različite polazne osnovice, s obzirom da se do 20II. godine porezno opterećenje mjerilo u odnosu na cjenovno najpopularnije kategorije cigareta, a od 20I2. u odnosu na ponderiranu prosječnu maloprodajnu cijenu cigareta. Stoga promjene u razdoblju 2005.-20I4. (grafikon 3) odražavaju razlike u poreznom opterećenju između dvije referentne cijene.

\section{GRAFIKON 3.}

Promjene u poreznom opterećenju cigareta (2005.-20I4.)

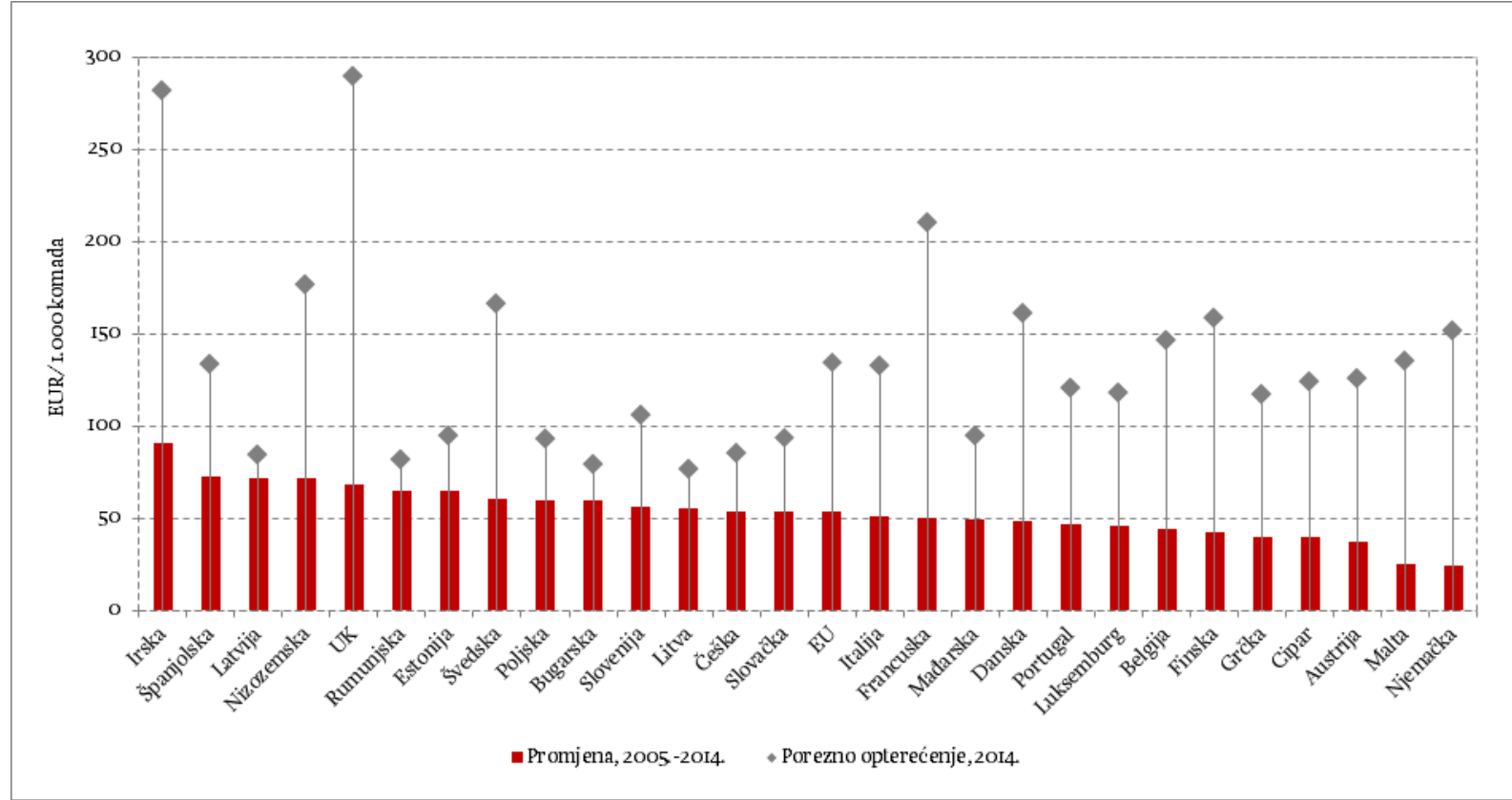

Izvor: European Commission - CIRCABC baza podataka (I990-20I4); izračun autorice. 
Grafikon 4. prikazuje razlike u poreznom opterećenju cjenovno najpopularnije kategorije cigareta $\mathrm{i}$ ponderirane prosječne maloprodajne cijene. U nekim novim članicama (Poljska, Mađarska, Latvija i Litva) razlike ukazuju na veliki raspon cijena između najjeftinijih, a time i najpopularnijih cigareta i skupih brendova.

\section{GRAFIKON 4.}

Udio poreza u cijeni cigareta $u$ EU (2005.-20I4.)

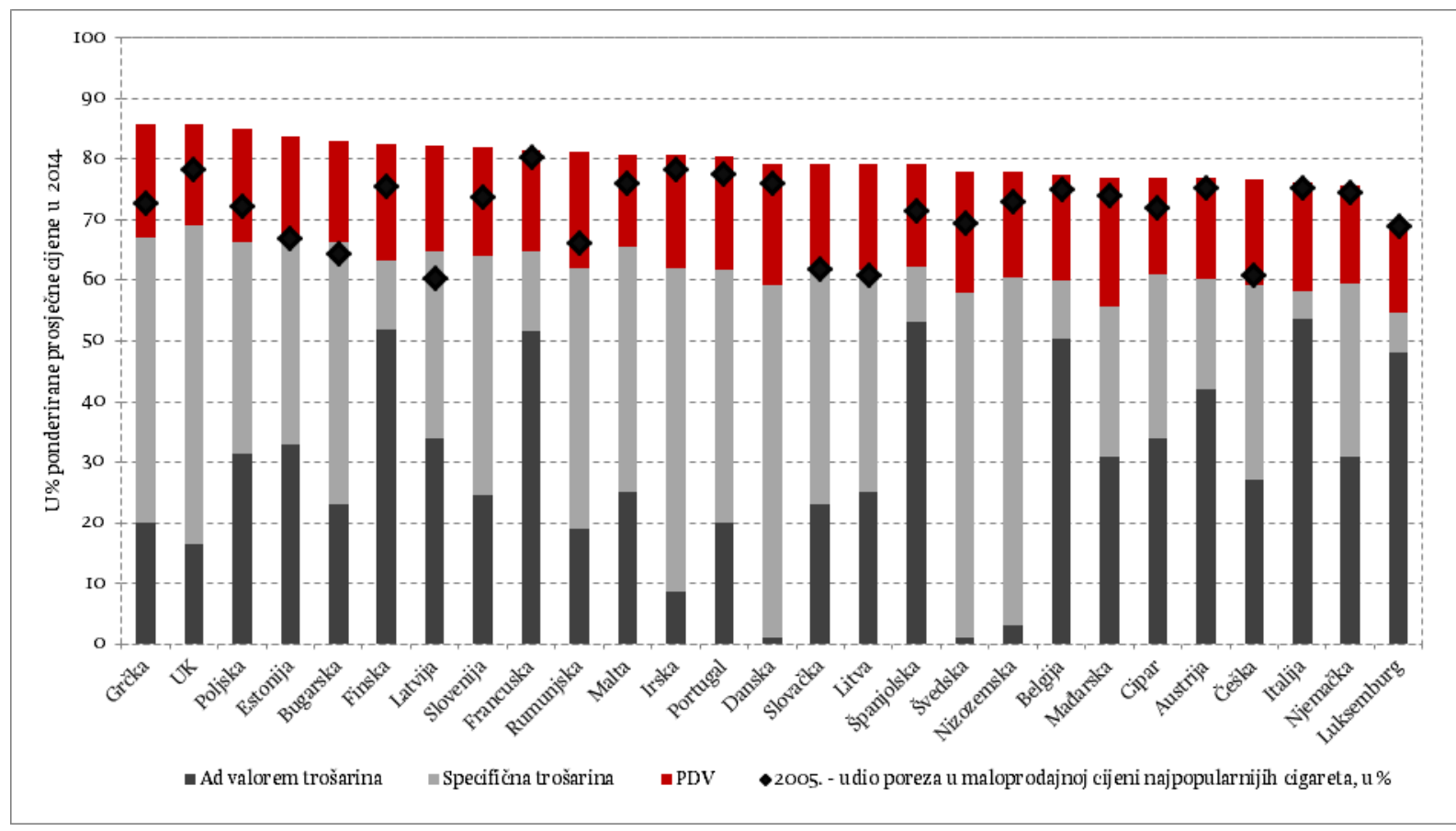

Izvor: European Commission - CIRCABC baza podataka(I99o-20I4); izračun autorice.

Treba imati $u$ vidu da se analiza trošarina i udio ukupnog poreznog opterećenja u cijeni cigareta odnosi na razdoblje početka globalne ekonomske krize i posljedica koje je ona izazvala. U cilju fiskalne konsolidacije veliki broj država članica povećao je stopu PDV-a što je utjecalo ne samo na visinu maloprodajnih cijena cigareta i strukturu poreznog opterećenja cigareta, nego i na iznos ponderiranog prosjeka maloprodajnih cijena.

\section{PROGES PRIBLIŽAVANJA TROŠARINA NA GIGARETE U EUROPSKOJ UNIJI}

U posljednjih deset godina proces promjena strukture trošarina na razini EU ostvario je značajne pomake. U usporedbi s 2005. kad su prisutne velike razlike i rasponi u visinama stopa ad valorem trošarina, u 20I4. većina članica pripada skupini u kojoj se stope kreću između 20 i 30\%. Najveće promjene dogodile su se u iznosima specifičnih trošarina. Većina članica 2005. primjenjuje specifičnu trošarinu u iznosu do 25 eura za 1.ooo komada cigareta, a danas se većinom iznosi kreću u rasponu od 50 do Ioo eura za 1.ooo komada (grafikon 5). 
GRAFIKON 5.

Razvoj procesa harmonizacije na duhanske preradevine u EU (2005.-20I4.)

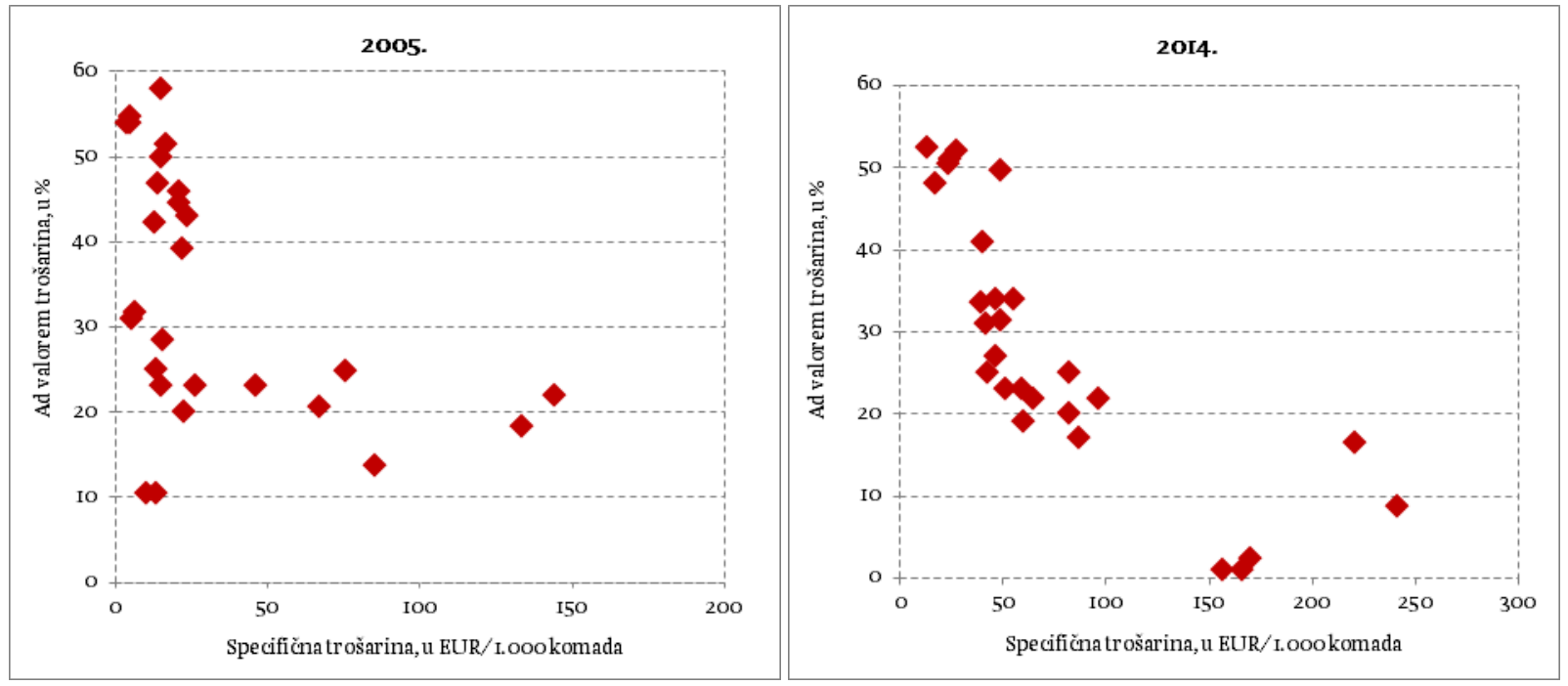

Izvor: European Commission - CIRCABC baza podataka (I990-2OI4).

Kao posljedica različite prilagodbe politici približavanja stopa među zemljama, raspon između najviše i najniže stope ad valorem trošarine povećan je nakon 20Io. godine. U članicama je s jedne strane, došlo do blagog smanjenja maksimalne stope, dok je s druge strane prisutan značajan pad najniže stope. To je ujedno i razlog naglog povećanja $\mathrm{u}$ rasponima stopa i njegova zadržavanja na visokoj razini (grafikon 6). Dva su razloga povećanja raspona između minimalne i maksimalne specifične stope trošarine (grafikon 2): (I) spora prilagodba zemalja koje imaju visoku stopu ad valorem trošarine, i (2) brzog rasta iznosa specifične trošarine u državama koje su tradicionalno imale visoke stope specifične trošarine i nižih stopa od prosječnih stopa ad valorem trošarine (Velika Britanija, Irska, Njemačka, Danska, Portugal,...).

\section{GRAFIKON 6.}

Raspon stopa trošarina na cigarete u EU-27
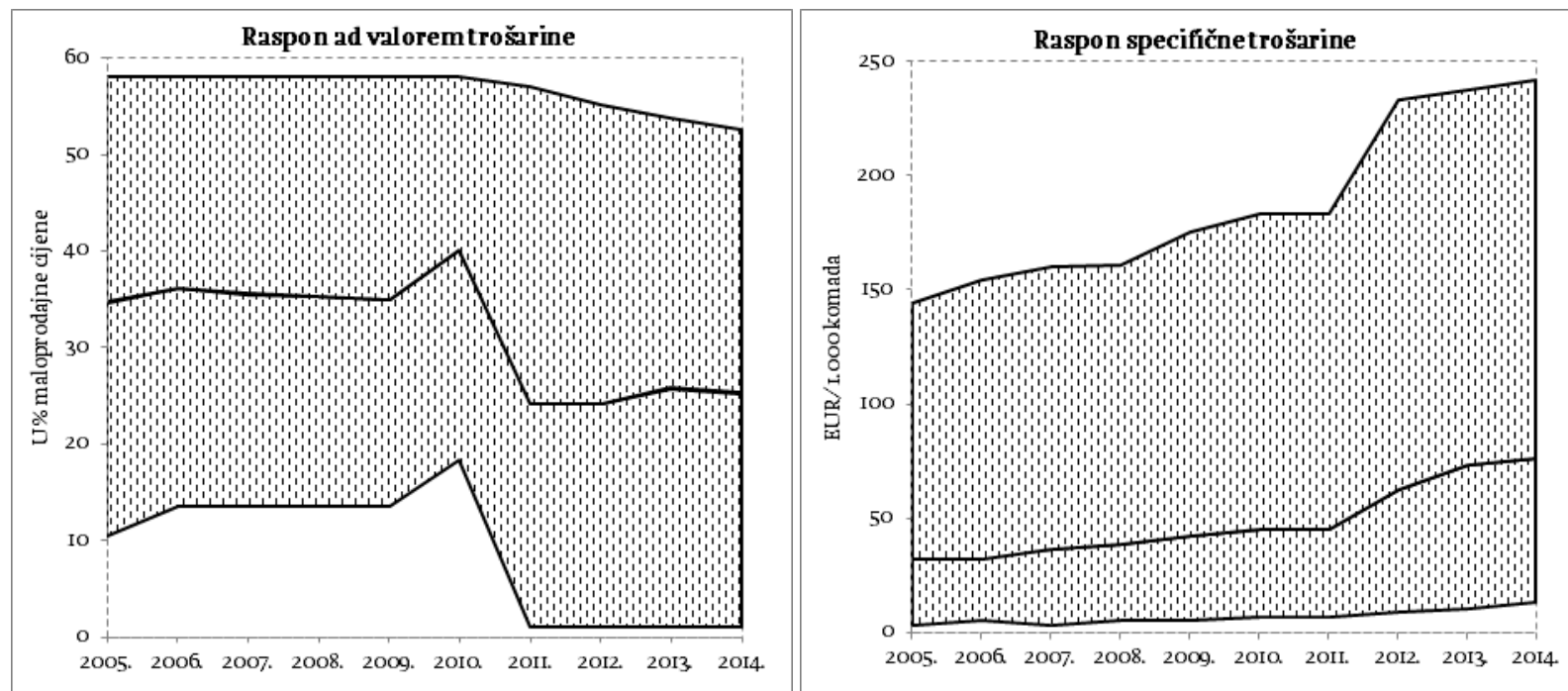

Izvor: European Commission - CIRCABC baza podataka (I990-20I4); izračun autorice. 
Kao posljedica nekoordiniranih promjena $\mathrm{u}$ trošarinskim politikama članica prosječna stopa ad valorem trošarine na razini EU-a porasla je za 2,3 postotna poena u razdoblju 2005.-2010., dok je u posljednje četiri godine smanjena za 8 postotnih poena. S druge strane, kontinuirano povećanje specifične trošarine rezultiralo je na razini EU-a snažnim povećanjem prosječne specifične trošarine $\mathrm{s}$ 27,8 eura u 2005. na 63 eura za 1.00o komada u 2014. godini.

Nejedinstvena politika u primjeni ad valorem trošarine dovela je u starim članicama ("EU-I5") do pogoršanja koeficijenta varijacije, ne samo za EU-I5 nego i za cijelu EU (grafikon 7). S druge strane, brza prilagodba novih članica (NMS) minimalnim standardima EU-a dovela je do smanjenja raspršenosti stopa oko prosjeka skupine. Kao rezultat politike kontinuiranog povećanja stope (grafikon 7) specifične trošarine primjetno je kako u starim tako i u novim članicama konstantno smanjenje raspršenosti stopa.

\section{GRAFIKON 7.}

Promjene stopa trošarina na cigarete u EU-27 (2005.-2014.)

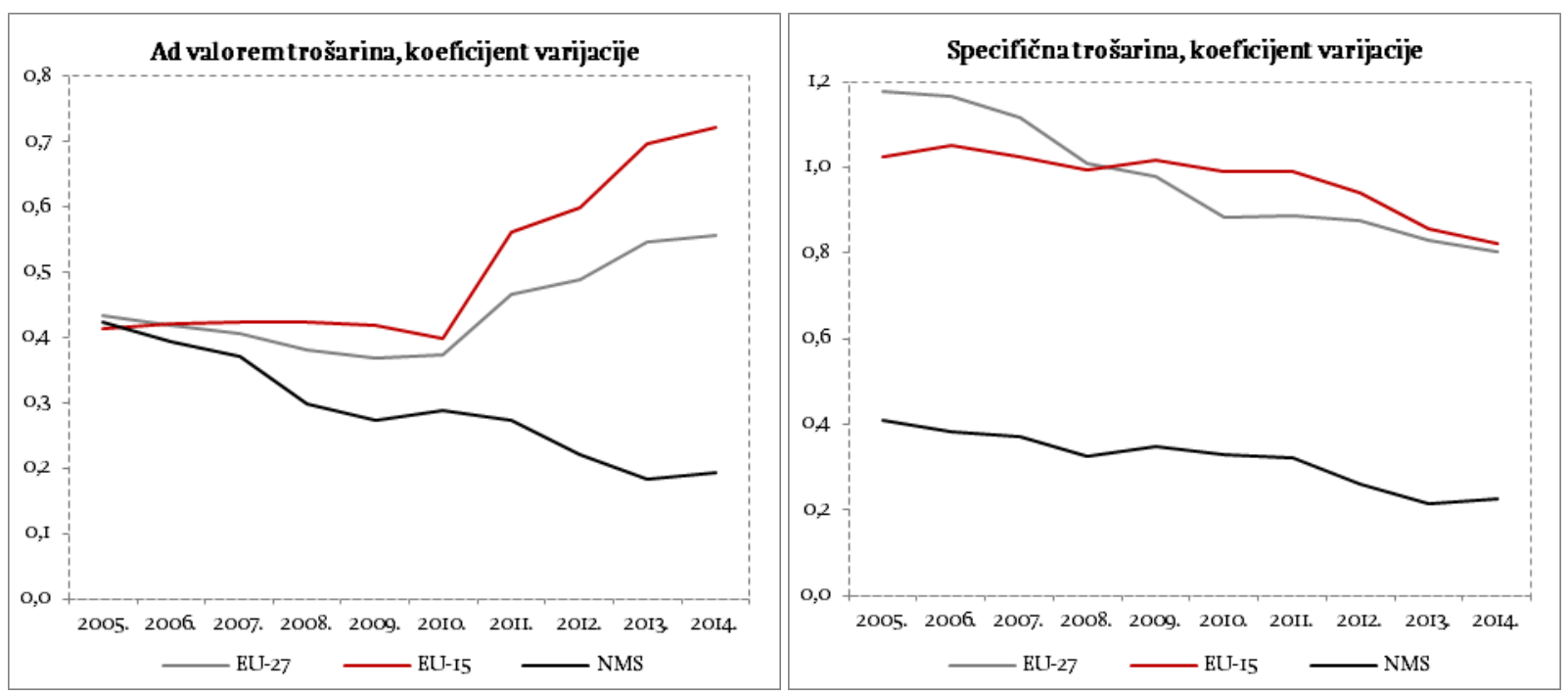

Izvor: European Commission - CIRCABC baza podataka (1990-2014); izračun autorice.

Povećanje trošarina na cigarete dovelo je u članicama do postupnog povećanja poreznog opterećenja u cijeni cigareta. Grafikon 8 prikazuje trend rasta poreznog opterećenja uz održavanje jednakih raspona. Maksimalne vrijednosti odnose se na stare, a minimalne na nove članice.

Promatrajući trendove iz kojih proizlaze zaključci potrebno je imati na umu da niz podataka o trošarinskom opterećenju i cijenama $u$ članicama nije u potpunosti dosljedan. Zahvaljujući važećim standardima, podaci i iznos trošarinskog opterećenja u cijeni cigareta temelje se u razdoblju 2005.20II. na cjenovno najpopularnijoj kategoriji, a u razdoblju 2012.-20I4. na ponderiranoj prosječnoj maloprodajnoj cijeni. U svakom slučaju, trendovi pokazuju rast maloprodajne cijene cigareta $u$ zemljama EU-a dok rasponi između najskupljih i najjeftinijih cigareta ostaju isti. Međutim, silazni koeficijent varijacije poreznog opterećenja i cijena pokazuje smanjenje varijabilnosti i u starim i novim članicama do 20II. godine, dok od 2012. koeficijent varijacije u starim članicama raste. Razlog može biti u različitim osnovicama za primjenu ad valorem trošarine (ponderirana prosječna maloprodajna cijena $\mathrm{u}$ odnosu na cjenovno najpopularnije kategorije), ali i u snažnom rastu specifičnih trošarina u nekim članicama (Velika Britanija, Francuska, Švedska,...) što je dovelo do povećanja cijena. 
GRAFIKON 8.

Promjene cijena i poreznog opterećenja cigareta u EU-27 (2005.-20I4.)

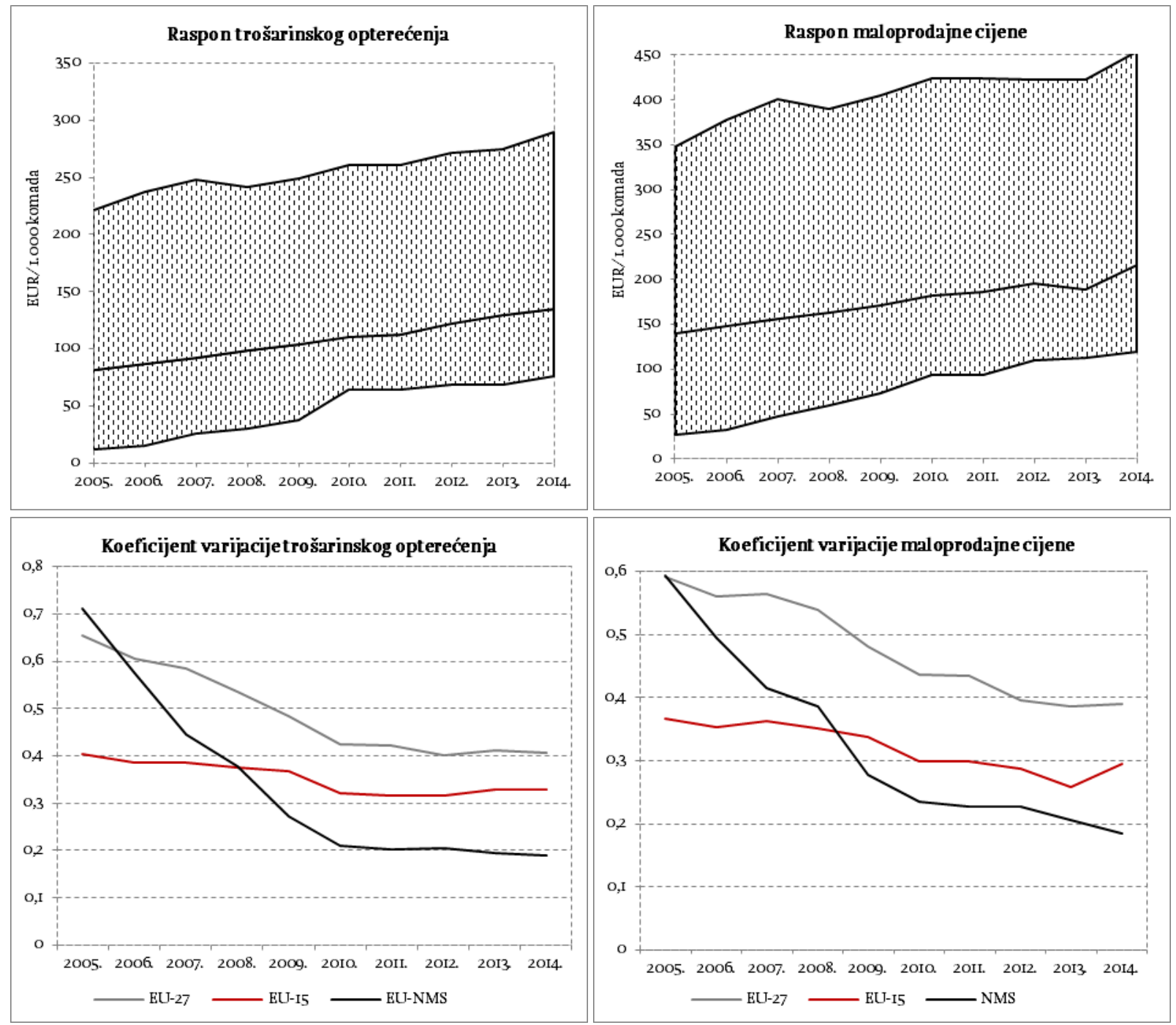

Izvor: European Commission - CIRCABC baza podataka (I990-20I4); izračun autorice.

Prethodna analiza pokazala je visoki stupanj homogenosti trošarinskih politika novih članica EU-a. Dva su glavna razloga za to. Prvo, sve su nove članice bile u sličnoj početnoj poziciji prije ulaska u EU. Drugo, postupak harmonizacije minimalne trošarine sa 64 eura, odnosno go eura, provodi se u novim članicama politikom istodobnog smanjenje ad valorem trošarine i povećanjem specifične trošarine. Pokazatelj varijacije raspona stopa trošarina nije relevantan za analizu, jer su tijekom razdoblja prisutne ekstremne vrijednosti specifične i ad valorem trošarine u starim članicama EU-a. Iz gore navedene analize može se zaključiti da stare članice također imaju najviše porezno opterećenje i cijene cigareta. Međutim, iz toga se ne može zaključiti da trendovi u oporezivanju cigareta u novim članicama nisu relevantni za politike približavanja trošarina EU-a. Analiza raspona stopa ukazuje na značajno smanjenje stope i sužavanje raspršenosti ad valorem trošarina (grafikon 9). Primjetan je stalni rast specifičnih trošarine uz povećanje raspona između najviše i najniže stope. Ovakvi trendovi vode do povećanja trošarinskog opterećenja, tako da je 2010. postignut propisani minimum od 64 eura za I.ooo komada i od tada se nastavlja proces harmonizacije s novom propisanom minimalnom trošarinom od 90 eura za I.ooo komada. Politika kontinuiranog smanjenja ad valorem stopa i 
povećanja iznosa specifične trošarine uzrokovalo je stalni rast cijena cigareta i smanjenju raspona cijena.

\section{GRAFIKON 9.}

Proces približavanja trošarina na cigarete u novim članicama EU-a (2005.-20I4.)

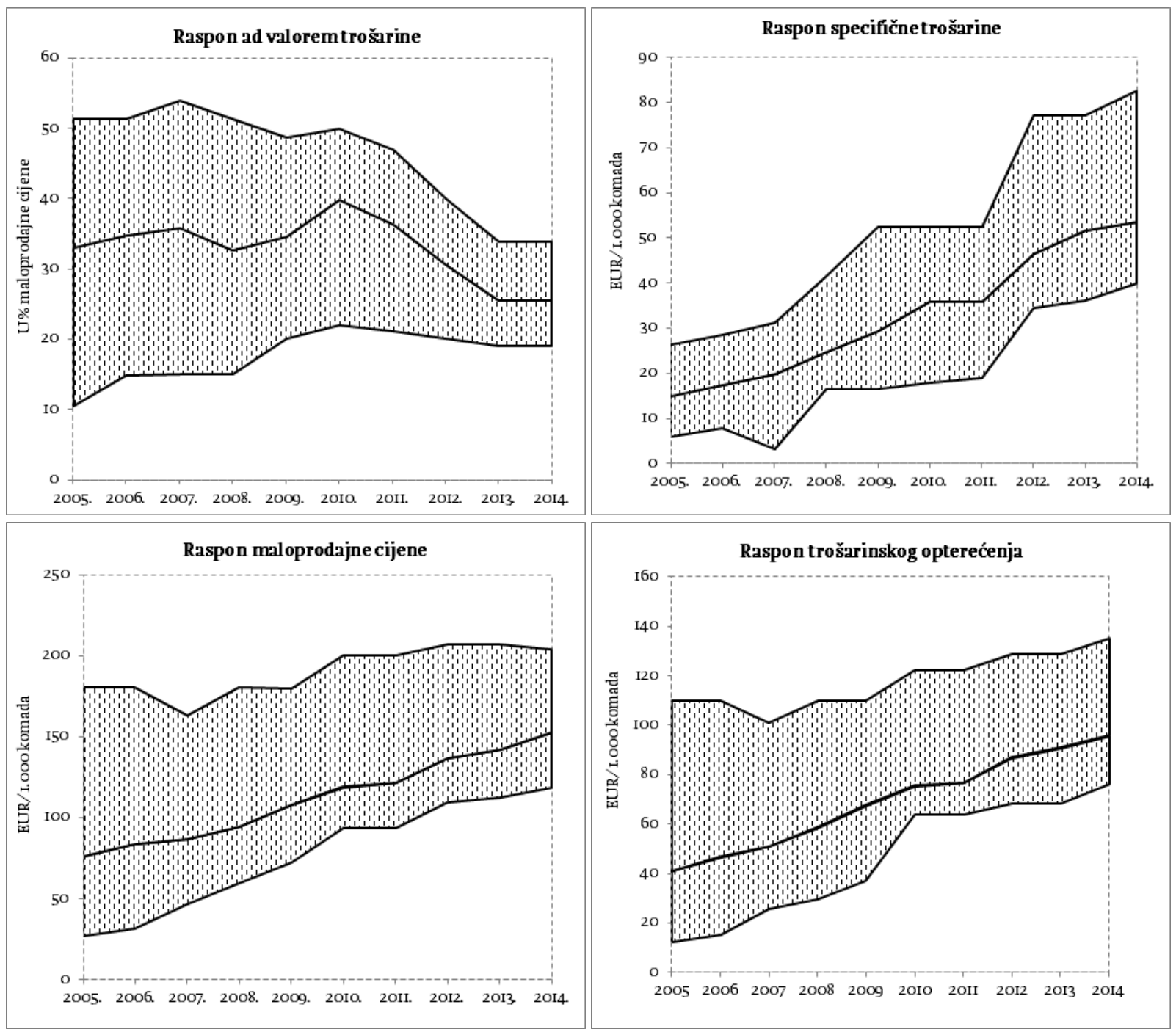

Izvor: European Commission - CIRCABC baza podataka (I990-20I4); izračun autorice.

Unatoč snažnoj polarizaciji između starih i novih članica zamjetno je postupno približavanje tih dviju skupina. To govore sljedeći pokazatelji. Prvo, prosječno trošarinsko opterećenje cigareta u novim članicama u odnosu na prosječno trošarinsko opterećenje u starim članicama povećalo se u razdoblju 2005.-2014. s 36,3\% na 57,6\% (grafikon 3). Drugo, očigledno je približavanje visina cijena cigareta. Prosječna cijena cigareta u novim zemljama članicama u 2005. godini iznosila je 39,9\% prosječne cijene u zemljama EU-I5, a 20I4. godine postotak je povećan na 56,8\% (grafikon Io).

Analiza koeficijenta varijacije ukazala je na duboku podjelu između starih i novih članica koja također utječe na tempo procesa približavanja. Međutim, može se zaključiti da je EU u posljednjih deset godina svojom politikom trošarina na cigarete, unatoč svim objektivnim preprekama, uspjela usmjeriti nacionalne trošarinske politike u smjeru procesa približavanja. 
GRAFIKON IO.

Postupak približavanja u novim članicama EU-a $(u$ \%)

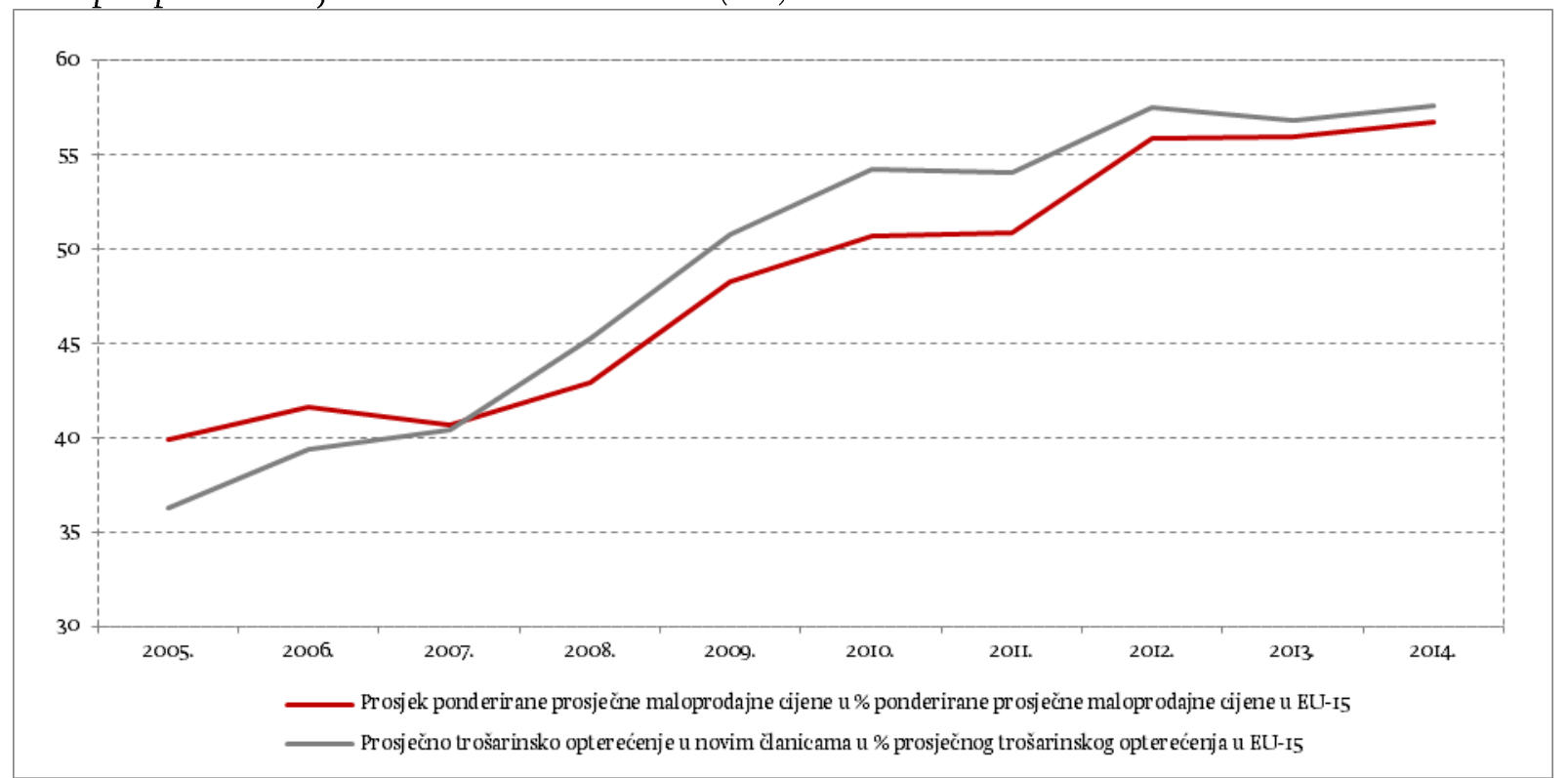

${ }^{a}$ Aritmetički prosjek skupine novih članica.

${ }^{b} U$ razdoblju 2005.-20II. primjenjuje se kriterij cjenovno najpopularnije kategorija cigareta, a u razdoblju 20I2.-20I4. ponderirane prosječne maloprodajne cijene cigareta.

Izvor: European Commission - CIRCABC baza podataka (I990-20I4); izračun autorice.

\section{TRENDOVI KRETANJA PRIHODA OD TROŠARINA NA DUHANSKE PRERAĐEVINE}

Kako što je i očekivano, kontinuirano povećanje trošarina na cigarete u članicama dovelo je do porasta maloprodajnih cijena i slijedom toga do velikog smanjenje potrošnje cigareta. Usporedba potrošnje cigareta u 2013. s onom u 2005. pokazuje da je pad potrošnje zabilježen u svim članicama, a u nekima od njih potrošnja je prepolovljena. Porast potrošnje cigareta u Finskoj 20I3. rezultat je akumulacije određene količina cigareta prije povećanja trošarina u 20I4. (grafikon II).

\section{GRAFIKON II.}

Promjene u potrošnji cigareta u članicama EU-a (2005.-2013.)

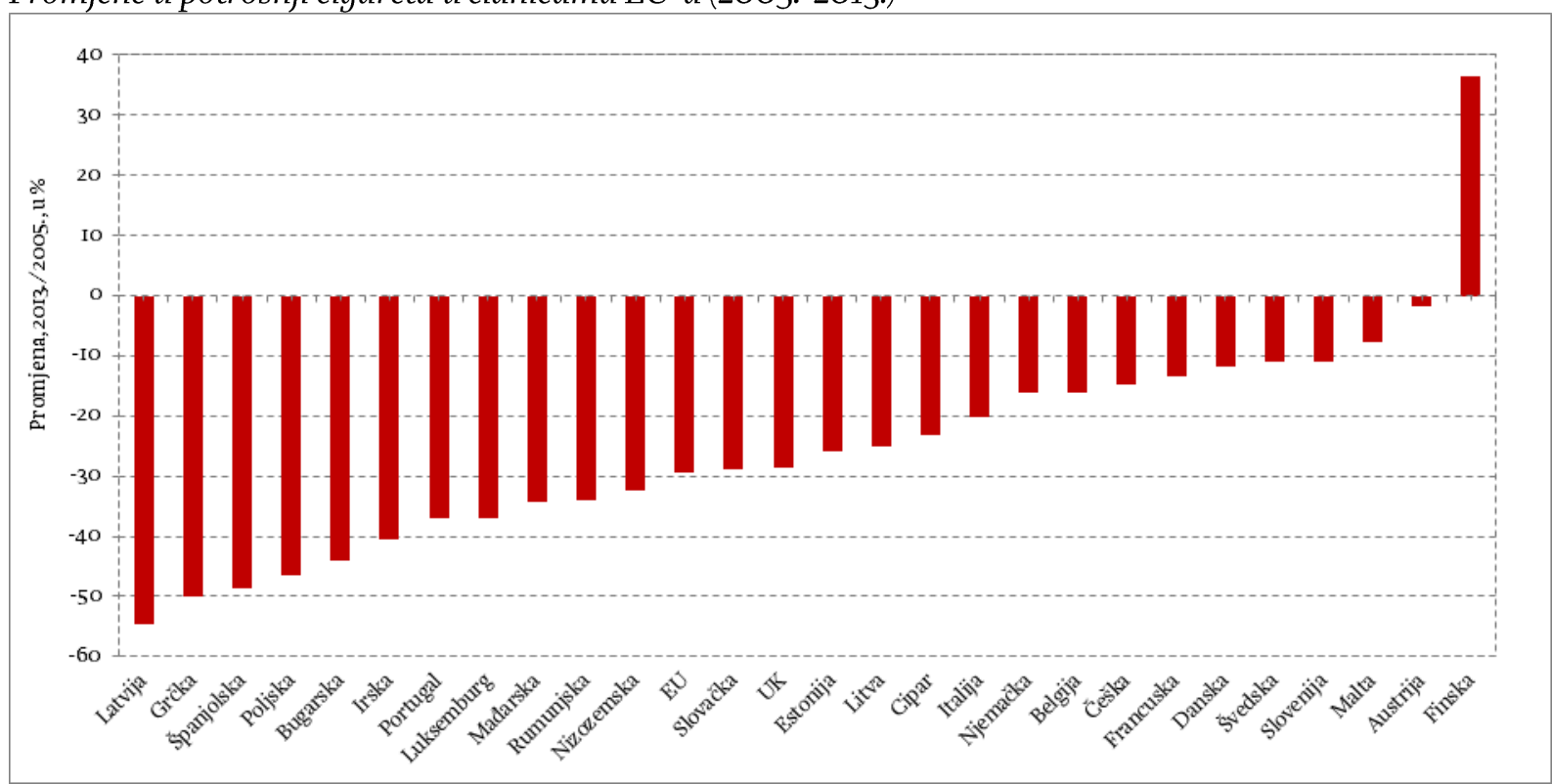

Potrošnja u Grčkoj u 20I3. odnosi se na razdoblje siječanj-studeni.

Izvor: European Commission - CIRCABC baza podataka (1990-20I4); izračun autorice. 
Povećanje poreznog opterećenja cigareta nije bio jedini razlog smanjenja potrošnje cigareta $u$ članicama EU-a. Drugi je razlog bila nedosljedna politika oporezivanja duhanskih prerađevina u EU u kojoj sitno rezani duhan ima povoljniji porezni položaj. Povećanje minimalne trošarine na cigarete $u$ EU na 90 eura za 1.ooo komada nije pratilo odgovarajuće povećanja trošarina na sitno rezani duhan. To je potrošačima većine zemalja dalo snažan poticaj za masovne migracije s tržišta cigareta na tržište sitno rezanog duhana. Potrošnja sitno rezanog duhana u nekim se članicama u samo nekoliko godina udvostručila, dok je u Rumunjskoj i Sloveniji zabilježen enormni rast (grafikon 12).

Novi trendovi donijeli su novi analitički pristup istraživanjima tržišta duhana. Analize tržišta duhana do prije nekoliko godina bile su ograničene samo na tržište cigareta dok je udio ostalih duhanskih prerađevina bio zanemariv. Pojavom sitno rezanog duhana kao snažnog supstituta cigareta bilo je neophodno uzeti u obzir ukupne trendove za sve duhanske prerađevine. Međutim, razmatranje samo potrošnje cigareta bez uključivanja sveukupnih trendova u potrošnji duhanskih prerađevina moglo bi stvoriti iluziju u kojoj su trendovi potrošnje duhana bili u skladu s ciljevima zdravstvene politike.

Povećanjem poreznog opterećenja cigareta u EU do određenog momenta donosi porast prihoda od trošarina, ali pojavom snažnog pada potrošnje povećanje prihoda prestaje pa je u nekim zemljama čak zabilježen negativna vrijednost naplaćenih prihoda.

\section{GRAFIKON I2.}

Promjene u potrošnji sitno rezanog duhana u razdoblju 2008.-2013. (2008.=I00), u \%

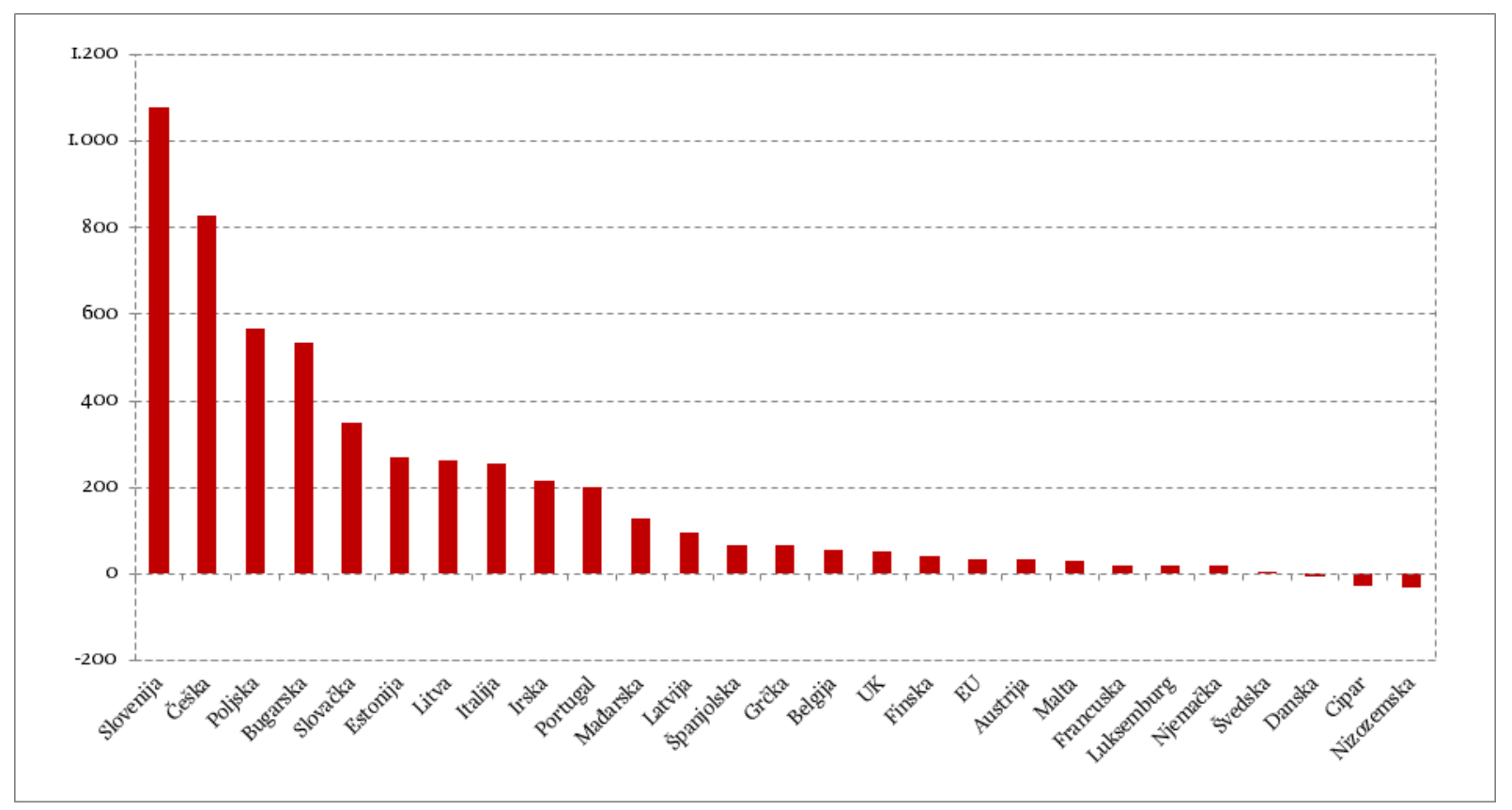

${ }^{a}$ Potrošnja u Grčkoj u 2013. odnosi se na razdoblje siječanj-studeni. ${ }^{b}$ Rumunjska je izostavljena zbog ogromnog rasta od preko $2.000 \%$.

Izvor: European Commission - CIRCABC baza podataka(I990-20I4); izračun autorice. 
GRAFIKON I3.

Godišnje promjene potrošnje i prihoda od duhanskih prerađevina u EU-u (u \%)

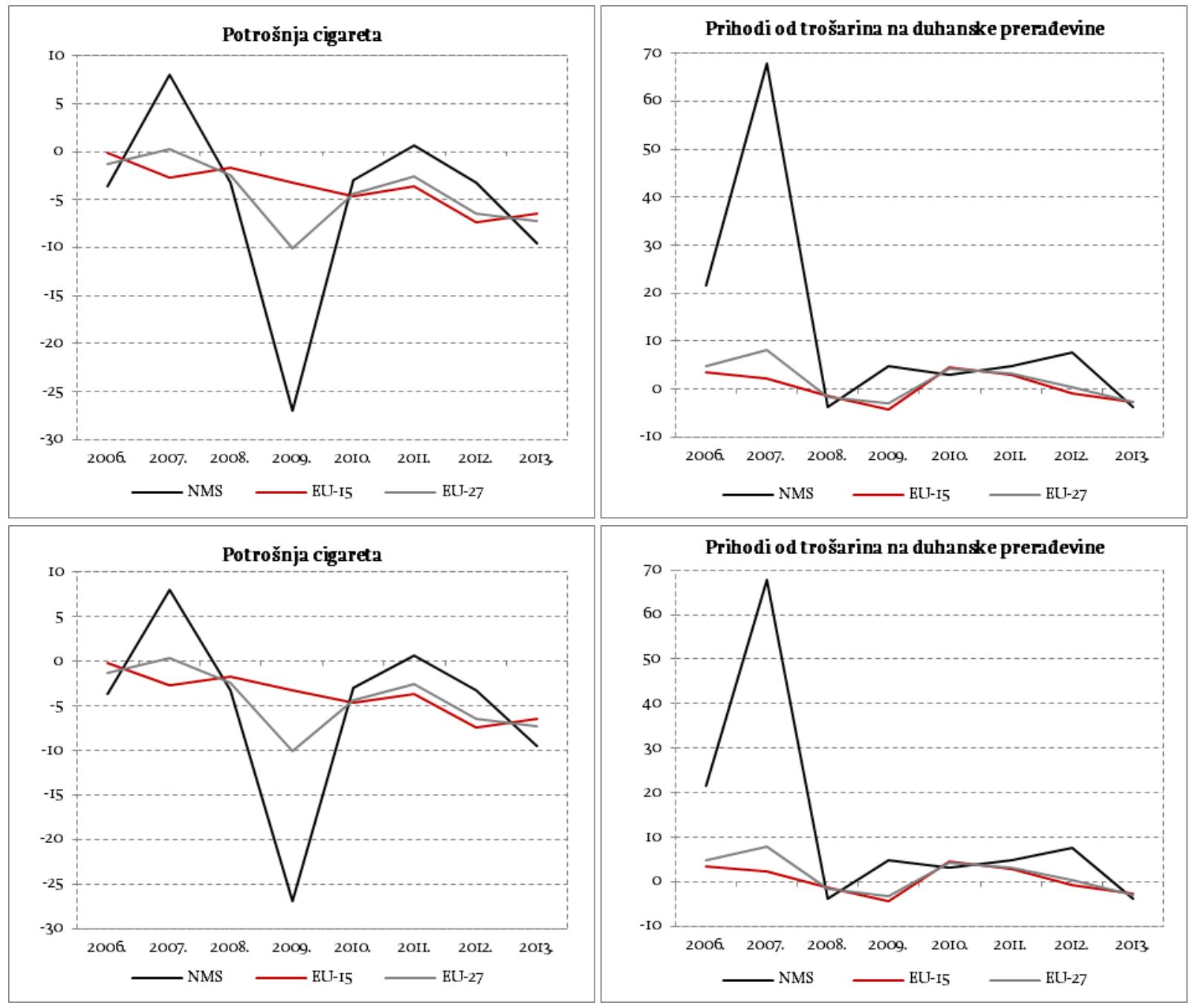

Izvor: European Commission - CIRCABC baza podataka (I990-20I4); osim prihoda za Rumunjsku koji su pribavljeni od Ministarstva javnih financija Rumunjske; izračun autorice.

Potrošnja cigareta i naplata prihoda u novim članicama podložna je snažnim oscilacijama zbog harmonizacije s minimalnom trošarinom od 64 eura, ali i zbog porasta supstitucije cigareta sitno rezanim duhanom. Kao što se i očekivalo, u prvih nekoliko godina povećanje trošarina u novim članicama rezultiralo je ogromnim rastom prihoda, ali nakon stabilizacije prihoda došlo je do usporavanja rasta. S druge strane, potrošnja cigareta u EU-I5 se bez većih oscilacija stalno smanjuje, dok prihodi osciliraju u rasponu od $-5 \%$ do $5 \%$ (grafikon 13). Razmjeri pada potrošnje cigareta i poreznih prihoda najvidljiviji su iz usporedbe s polaznom 2005. godinom. U 2013. potrošnja cigareta $u$ EU-I5 smanjena je na 70\% potrošnje iz 2005. Uz prisutan silazni trend prihodi od trošarina na cigarete $\mathrm{u}$ istom razdoblju porasli su $4 \%$ iako je porezno opterećenje cigareta u prosjeku poraslo $47 \%$. Iako zbog većeg poreznog opterećenja, trendovi u EU-I5 uglavnom određuju trendove $u$ EU-27, zanimljivo je analizirati trendove $\mathrm{u}$ novim članicama. Povećanje poreznog opterećenja cigareta tijekom devetogodišnjeg postupka harmonizacije u prosjeku iznosi 133\% koje je rezultiralo rastom prihoda od trošarina od I31\%. U isto vrijeme potrošnja cigareta pala je na 63\% potrošnje iz 2005. godine. Rezultati navedene analize potvrđeni su trendovima u članicama u razdoblju 20I1.-2013., kada su najizraženiji učinci supstitucije cigareta. Deset članica EU-27 koje ostvaruju 37\% prihoda u posljednje je tri godine 
zabilježilo negativne trendove $u$ naplati prihoda od trošarina na cigarete. Od tih deset članica devet pripadaju EU-I5 od kojih četiri članice u sve tri godine bilježe pad prihoda s tendencijom pogoršanja, a kod ostalih zabilježen je pad prihoda u posljednje dvije godine. S druge strane, pet novih članica bilježi snažan rast prihoda. Od toga njih pet bilježi stabilan ili umjeren rast, dok je samo Rumunjska zabilježila nulti rast. Imajući $u$ vidu da je trošarina $u$ starim članicama znatno viša nego $u$ novim postojeći trendovi pokazuju negativne strane brzog porasta trošarina, koji s jedne strane ne prate odgovarajuće mjere za sprječavanje utaje poreza i prijevara, a s druge strane odgovarajuća politika oporezivanja supstituta.

Smanjenje potrošnje cigareta uz porast potrošnje sitno rezanog duhana, osim fiskalnih gubitaka, rezultiralo je i promjenama u strukturi prihoda od trošarina (grafikon I4).

\section{GRAFIKON I4.}

Struktura prihoda od trošarina u EU-u (20I3.), $и$ \%

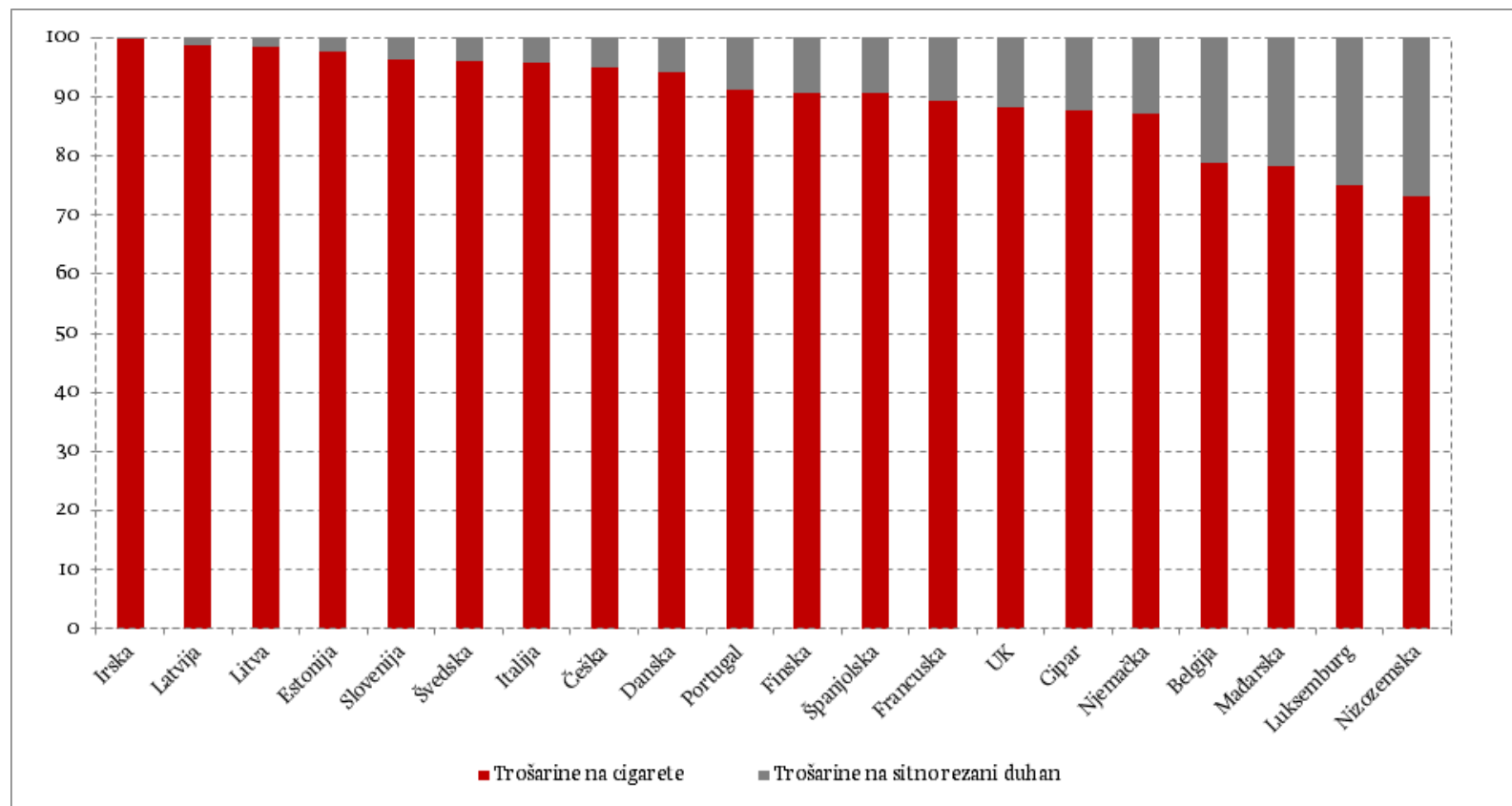

Izvor: European Commission - CIRCABC baza podataka(I990-20I4); izračun autorice.

U usporedbi sa zanemarivim udjelom u prethodnim godinama udio prihoda od trošarina na sitno rezani duhan ubrzano raste. Ovaj je trend posljedica kumulativnog učinka nominalnog smanjenja prihoda od trošarina na cigarete i nominalnog rasta trošarina na sitno rezani duhan, koji je posljedica nekonzistentne trošarinske politike EU-a na sitno rezani duhan.

\section{REDEFINIRANJE POLITIKE OPOREZIVANJA OSTALIH DUHANSKIH PRERADEVINA U EUROPSKOJ UNIJI}

Analiza politike i trendova u potrošnji i prihodima ukazala je na velike iskrivljenosti na tržištu cigareta koje su rezultat različitog oporezivanja supstituta i slabih mehanizama sprječavanja porezne utaje. Osim ugrožavanja naplate prihoda, zamjena cigareta sitno rezanim duhanom ozbiljno ugrožava ostvarivanje ciljeva zdravstvene politike. Umjesto da bude instrument koji će obeshrabriti potrošnju duhana, trošarinska politika ne samo da omogućuje potrošačima s nižim dohocima zadržavanje jednakog obujma potrošnje duhana nego ih još potiče na kupnju jeftinijeg i nekvalitetnijeg duhana. 
Neodrživost postojećeg stanja ukazuje na potrebu hitnog redefiniranja trošarinske politike u dijelu koji se odnosi na sitno rezani duhan i ostale supstitute cigareta. Harmonizacijom trošarina na supstitute cigarete trebao bi se zaustaviti daljnji rast potrošnje legalnih i nelegalnih supstituta cigareta i dugoročno stabilizirati tržište cigareta kako bi se nastavilo s primjenom mjera kojima je cilj obeshrabriti potrošnju duhana.

Već dugi niz godina oporezivanje ostalih duhanskih prerađevina (cigara, cigarilosa, sitno rezanog duhana, ostalog duhana za pušenje) smatralo se, zbog manjih udjela u poreznim prihodima i tržištu duhana, manje važnim segmentom politike oporezivanja duhana. Prema Direktivama EU-a ostale duhanske prerađevine mogu se oporezivat samo ad valorem trošarinom ili samo specifičnom trošarinom ili kombinacija ad valorem i specifične trošarine. Uspostavom jedinstvenog tržišta određeno je oporezivanje sitno rezanog duhana u iznosu 30\% maloprodajne cijene koja uključuje sve poreze ili 20 eura za kilogram. Stope trošarina na sitno rezani duhan nisu se mijenjale do 200I. U razdoblju 2001.-2004. stopa je povećana s 24 eura na 32 eura za kilogram. Sljedeći povećanje zabilježeno je tek 20II. godini na 40 eura i zatim u 2013. na 47 eura za kilogram. Ostali duhan za pušenje trenutno se oporezuju s 22 eura za kilogram ili 20\% maloprodajne cijene.

Analiza politike oporezivanja sitno rezanog duhana u prethodnim godinama pokazuje značajan porast trošarinskog opterećenja sitno rezanog duhana u članicama EU-a. Uglavnom, povećanje poreznog tereta postignuto je (I) povećanjem postojeće specifične trošarine, (2) uvođenjem specifične trošarine i drastičnim smanjenjem ad valorem trošarine, ili (3) u članicama s mješovitom trošarinom povećanjem specifične trošarine i smanjenjem ad valorem trošarine.

U 20II. samo je šest članica oporezivalo sitno rezani duhan ad valorem trošarinom, a u 20I4. samo tri, od kojih su dvije u međuvremenu povećale stope. Mađarska je zadržala istu stopu ad valorem trošarine, a povećanjem stope PDV-a postigla je veće trošarinsko opterećenje. Broj članica koje su primjenjivale samo specifičnu trošarinu udvostručio se u razdoblju 20II.-20I4. sa 7 na 15 (uključujući i Hrvatsku), a broj zemalja koje imaju mješovitu trošarinu smanjen je sa I4 na Io. Suprotno trendovima u EU, Slovenija je neznatno povećala specifičnu trošarinu, ali od I. srpnja 20I4. primjenjuje i ad valorem, što je u konačnici dovelo do snažnog porasta trošarinskog opterećenja.

\section{GRAFIKON I5.}

Promjene u poreznom opterećenju sitno rezanog duhana u EU-27 (20II.-20I4.)

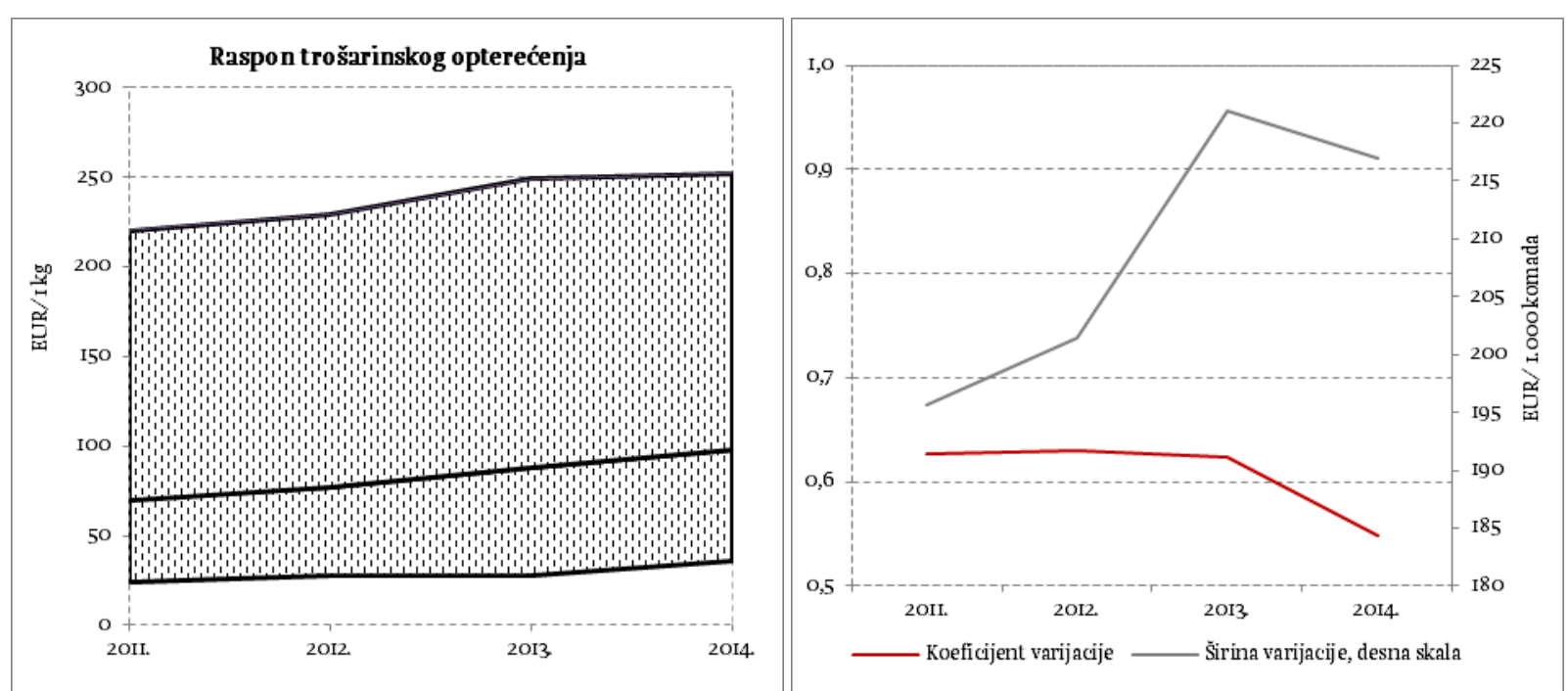

Izvor: European Commission - CIRCABC baza podataka (I990-20I4); izračun autorice. 
U cjelini, politikom povećanja trošarina na sitno rezani duhan u posljednje četiri godine ostvaren je 40\%-tni rast prosječnog poreznog opterećenja sitno rezanog duhana u EU (grafikon 15). U razdoblju 20IO--2013. nedosljedne politike članica dovele su do rasta širine varijacije. Tek su posljednje mjera konsolidacije trošarinske politike u 20I4. rezultirala znatnijim približavanjem stopa trošarina koje se ogleda u smanjenju koeficijenta varijacije i sužavanju širine varijacije.

Iako se $\mathrm{u}$ posljednjih nekoliko godina politika minimalne trošarine na sitno rezani duhan temeljila na snažnom rastu trošarina, stalno povećanje minimalne trošarine na cigarete $u$ određenoj je mjeri od početka umanjilo očekivani uspjeh ove politike. Čak i planirano povećanje trošarina na sitno rezani duhan do 2020. neće značajnije doseći razinu Cnossenovog optimalnog trošarinskog opterećenja sitno rezanog duhana od dvije trećine trošarinskog opterećenja cigareta, mjerenog za I kilogram duhana sadržanog u cigaretama (grafikon I6).

\section{GRAFIKON I6.}

Minimalne trošarine na cigarete i sitno rezani duhan u EU-u do 2020. (u EUR)

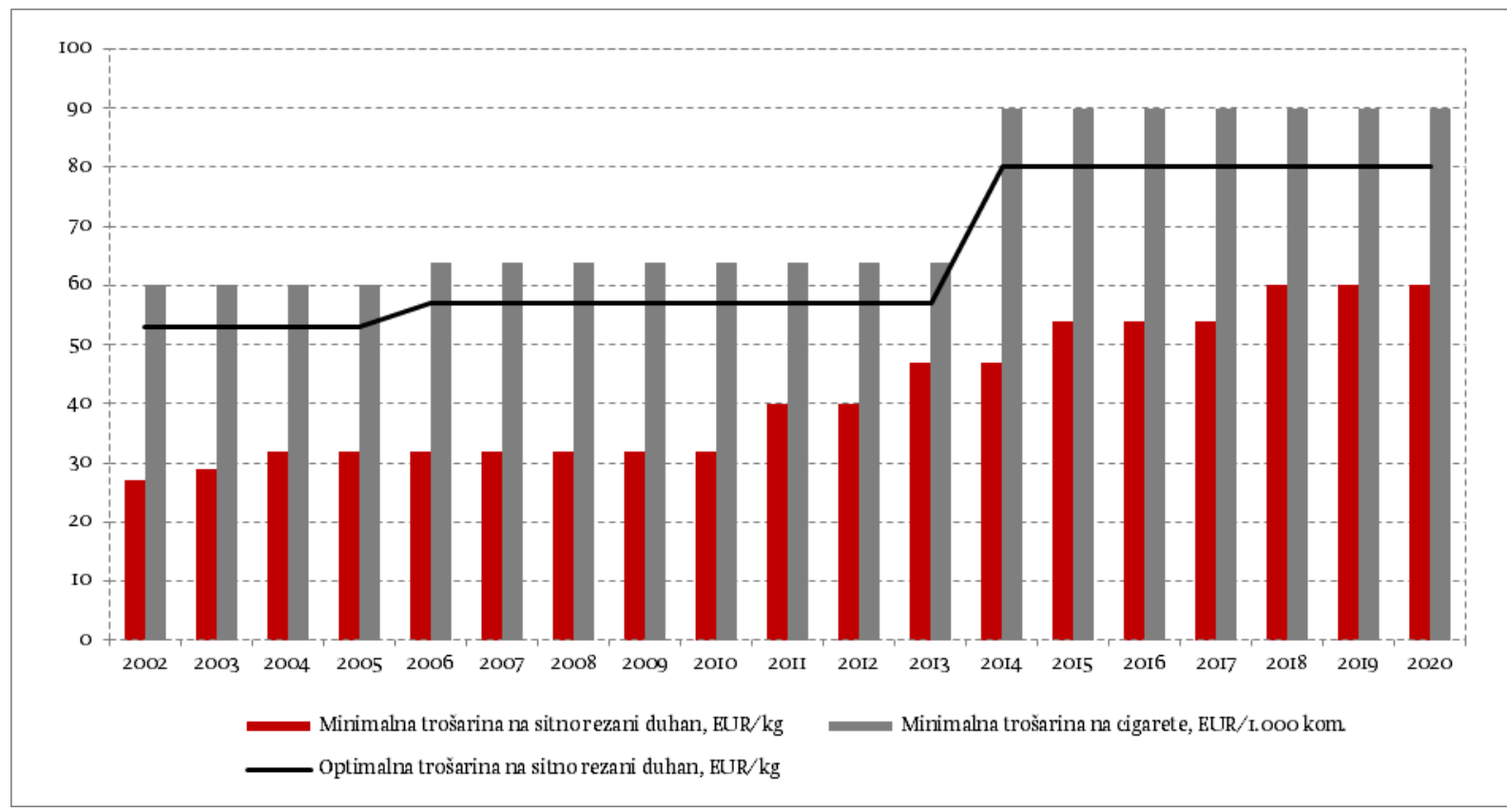

Izvor: izračun autorice.

Može se očekivati da će u sljedećim godinama visoko porezno opterećenje obeshrabriti potrošnju sitno rezanog duhana. Međutim, imajući u vidu iskustvo Poljske i nekih drugih država izvan EU-a potrebno je razmotriti oporezivanje i ostalih supstituta kao što su duhan za lule i ostale vrste duhana za pušenja. U ovom trenutku postoji veliki jaz između oporezivanja sitno rezanog duhana i ostalih duhana, koji će se u narednim godinama zbog daljnjeg povećanja trošarina na sitno rezani duhan još više povećavati. Osim toga, ekonomisti upozoravaju i na potrebu preciznijeg definiranja duhanskih prerađevina, što podrazumijeva pravilnu uspostavu stopa trošarina, osobito na sirovi duhan. Konačno, brzo rastuće tržište e-cigarete ozbiljno je upozorenje EU i članicama da se u narednim godinama može očekivati snažnija supstitucija cigareta e-cigaretama. Trenutačno, samo u dvije članice, Belgiji i Luksemburgu, e-cigarete se oporezuje ako sadrže ekstrakt duhana (Ramboll, 2OI4). 


\section{ZAKLJUǦAK}

Čini se da je veliki porast minimalne trošarine na razini EU-a od ključne važnosti za proces približavanja trošarinskih politika na razini EU-a. Iz analize trendova oporezivanja u razdoblju 2008.20I4. u EU može se zaključiti da se proces približavanja trošarinskih politika u EU postiže istodobnom provedbom dvaju procesa: kontinuiranim povećanjem trošarinskog opterećenja cigareta i kontinuiranom promjenom strukture trošarinskog opterećenja u korist specifične trošarine. Oba procesa vode do ubrzanog približavanja trošarinskog opterećenja cigarete i eliminacije jeftinijih brendova proizvedenih od nekvalitetnog duhana. Konačno, oporezivanje visokim trošarinama obeshrabruje potrošnju jeftinijeg duhana lošije kvalitete i u skladu je s ciljevima zdravstvene politike EU-a. S obzirom na okolnosti prije ulaska u EU trošarinske politike novih članica znatno su homogenije od onih u starim članicama. Analiza raspona odstupanja pokazala je da tempo procesa približavanja trošarinskih politika de facto ovisi o tempu prilagodbe starih članica koje su u prošlosti imale vrlo visoke stope ad valorem trošarine. Prilagodba tih država ukazuje na potrebu postupnog smanjenja ad valorem trošarine što bi se kompenziralo postupnim povećanjem specifične trošarine.

Analize trendova u oporezivanju duhana u EU potvrdile su hipotezu o važnosti unakrsne elastičnosti supstituta ili komplementarnih dobara pri oblikovanju trošarinske politike. Trošarinska politika u EU dugi niz godina temelji se na jednostranom povećanju trošarina na cigarete kako bi se obeshrabrila potrošnja. Međutim, zbog rastućih trendova u potrošnji sitno rezanog duhana, podaci o značajnom smanjenju potrošnje cigareta zapravo su varka. Visok stupanj supstitucije cigareta sitno rezanim duhanom doveo je do velikih poremećaja na tržištu duhana i jačanju crnog tržišta, tako da znatan dio potrošnje duhana i dalje u potpunosti ostaje neoporeziv ili u najboljem slučaju oporezuje se po znatno nižim stopama. Podaci o eroziji prihoda u posljednje dvije godine pokazuju da supstitucija nije bila prihodno neutralna i da će daljnje povećanje potrošnje sitno rezanog duhana na štetu potrošnje cigareta utjecati na financiranje proračuna članica i zdravstvenu politiku onih zemalja u kojima se prihodi od oporezivanja duhanskih prerađevina usmjeravaju i u zdravstvene programe. Sve dok je na tržištu prisutan sitno rezani duhan uglavnom slabije kvalitete od onoga koji se koristi za proizvodnju cigareta, nastavak trendova na tržištu duhana ozbiljno će ugrožavati trenutno postignute rezultate strategije smanjenja pušenja, pogotovo među socijalno ugroženim skupinama i mlađom populacijom koji su skloniji potrošnji supstituta. Činjenica da se za pušenje mogu koristiti i druge vrste duhana za pušenje, kao i e-cigarete, koji se oporezuju nižim stopama nego sitno rezani duhan, zahtijeva novi kvalitativniji pristup oblikovanju trošarinske politike EU-a. 


\section{REFERENGE}

I. Antić D., 20I4. Trends in collection of revenues from excise duties on tobacco: from the revenue "boom" to the tax evasion. OMA Bilten, (X)IO4. Dostupno na: <http://www.oma.uino.gov.ba/bilteni/Oma_Bilten_eng_IO4.pdf>.

2. Chaloupka, F. J. [et al.], 2002. Tax, price and cigarette smoking: evidence from the tobacco documents and implications for tobacco company marketing strategies. Tobacco Control II(Suppl I), str. i62-i72. doi: IO.II36/tc.II.suppl_I.i62

3. Chaloupka, F. J., Yurekli, A. i Fong, G. T., 2012. Tobacco taxes as a tobacco control strategy. Tobacco Control, 2I, str. 172-I80. doi: IO.II36/tobaccocontrol-20II-0504I7

4. Cnossen, S., 2006. Fiscal Policy in Action, Tobacco Taxation in the European Union. FinanzArchiv / Public Finance Analysis, (62) 2 [online]. Dostupno na: <http://www.libinst.cz/data/Cnossen.pdf〉.

5. Cooper, A. i Witt, D., 2012. The linkage between tax burden and illicit trade of excisable products: the example of tobacco. World Customs Journal, 6 (2), str. 4I-58 [online]. Dostupno na: 〈http://www.worldcustomsjournal.org/media/wcj/-20I2/2/Cooper_Witt.pdf〉.

6. De Beyer, J. i Yurekli, A., 200o. Curbing the epidemic in Indonesia. Watching Brief, East Asia and Pacific Region, No. 6 [online]. Dostupno na: <http://www.academia.edu/6032975/Curbing_the_TobaccoEpidemic_in_Indonesia>.

7. EU, 2007. Consultation Paper on the structure and rates of excise duty applied on cigarettes and other manufactured tobacco. European Commission - TAXUD [online]. Dostupno na: <http://ec.europa.eu/taxation_customs/resources/documents/common/consultations/tax/consult ation_paper_tobacco_en.pdf>.

8. European Commission, CIRCABC Database. Dostupno na: <https://circabc.europa.eu/faces/jsp/extension/wai/navigation/container.jsp>.

9. IFS, 20Io. Dimensions of Tax Design. The Mirrlees Review [online]. London: Institute for Fiscal Studies. Dostupno na: 〈http:/ /www.ifs.org.uk/mirrleesreview/dimensions/mirrlees_-dimensions.pdf〉.

Io. Lockwood, B. i Migali, G., 2008. Did the Single Market Cause Competition in Excise Taxes? Evidence from EU Countries. Warwick economic research papers, No. 847 [online]. Dostupno na: 〈http://www2.warwick.ac.uk/fac/soc/economics/research/workingpapers/2008/twerp_847.pdf〉.

II. Ramboll, 20I4. Study on the measuring and reducing of administrative costs for economic operators and tax authorities and obtaining in parallel a higher level of compliance and security in imposing excise duties on tobacco products [online]. Dostupno na: <http://ec.europa.eu/taxation_customs/resources/documents/taxation/excise_duties/tobacco_products/studies_reports/ramboll-tobacco-study.pdf .

I2. Rechel, B. i McKee, M. (ed.), 20I4. Facets of Public Health in Europe [online]. Open University Press. Dostupno na: <http://www.euro.who.int/_data/assets/pdf_file/ooo3/271074/Facets-of-PublicHealth-in-Europe.pdf?ua $=\mathrm{I}>$.

13. Smith, A. (ed. Canaan E.), 1976. An Inquiry into the Nature and Causes of The Wealth of Nations.

I4. Sunley, E., Yurekli, A. i Chaloupka, F. J., 2000. The design, administration, and potential revenue of tobacco excises, in J. Prabhat and F. J. Chaloupka, eds. Tobacco control in developing countries, Section V, Policy Directions. Oxford: Oxford University Press. Dostupno na: <http://siteresources.worldbank.org/INTETC/Resources/375990-I089904539172/407TO426.PDF〉.

15. Townsend, J., 1998. The Role of Taxation Policy in Tobacco Control in: I. Abedian [et al.], The Economics of Tobacco Control Towards an optimal policy mix (), [online]. Applied Fiscal Research Centre, University of Cape Town. Dostupno na: < http://idlbnc.idrc.ca/dspace/bitstream/IO625-/2632I/I/II8634.pdf〉.

16. WHO, 2008. MPOWER in action. Defeating the global tobacco epidemic [online]. Dostupno na: 〈http://www.who.int/tobacco/mpower/publications/mpower_2013.pdf?ua=I〉.

17. WHO, 20II. Technical Manual On Tobacco Tax Administration [online]. Dostupno na: 〈http://www.who.int/tobacco/publications/tax_administration/en/>.

I8. WHO, 2012. Tobacco Taxation and Innovative Health-care Financing. [online]. New Delhi: WHO Regional Office for South-East Asia. Dostupno na: 〈http://www.searo.who.int/tobacco-/documents/20I2pubi.pdf $>$.

19. World Bank, 1999. Curbing the epidemic: governments and the economics of tobacco control. Tobacco Control, No 8 [online]. Dostupno na: <http://tobaccocontrol.bmj.com/content/8/2/I96.full.html\#related-urlspp>.

20. Yurekli, A., 200I. Design and administer tobacco taxes [online]. Washington DC : World Bank. Dostupno na: <http://documents.worldbank.org/curated/en/2013/oI/1813634I/design-administer-tobaccotaxes $>$. 